\title{
District of Columbia v. Heller and Originalism
}

Lawrence B. Solum

Georgetown University Law Center, Ibs32@law.georgetown.edu

This paper can be downloaded free of charge from:

https://scholarship.law.georgetown.edu/facpub/854

http://ssrn.com/abstract=1495885

103 Nw. U. L. Rev. 923-981 (2009)

This open-access article is brought to you by the Georgetown Law Library. Posted with permission of the author. Follow this and additional works at: https://scholarship.law.georgetown.edu/facpub

Part of the Constitutional Law Commons, Jurisprudence Commons, Legal Theory Commons, Rule of Law Commons, and the Second Amendment Commons 


\section{DISTRICT OF COLUMBIA V. HELLER AND ORIGINALISM}

\section{Lawrence B. Solum*}

INTRODUCTION: THE EXEMPLARY SIGNIFICANCE OF HELLER 924

I. HELLER AND THE EVOLUTION OF CONTEMPORARY ORIGINALIST THEORY .............. 926

A. Original Intentions of the Framers ............................................................. 927

B. The Misconceived Quest and the Original Understanding of Original

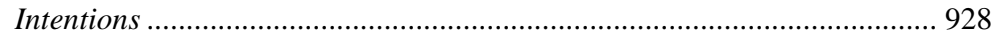

C. Original Understanding of the Ratifiers..................................................... 930

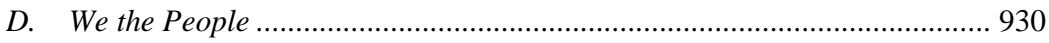

E. Original Public Meaning and the New Originalism................................... 933

F. Original Applications and Original Methods........................................... 934

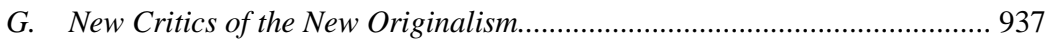

H. District of Columbia v. Heller..................................................................... 939

II. LiNGUISTIC MEANING AND LEGAL ConTENT ............................................................ 940

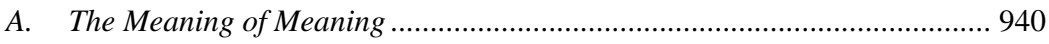

B. Linguistic Facts and Normative Constitutional Theory ............................. 941

C. Linguistic Facts and the Fixation of Meaning........................................... 944

D. Clause Meaning or Framers' Meaning ................................................... 947

E. Semantic Content and Legal Content ....................................................... 953

III. Teleological Meaning And Justice Stevens’s Dissent ................................... 955

A. The Two Clauses of the Second Amendment ............................................... 955

B. Justice Stevens's Dissent and Teleological Meaning ................................. 957

\footnotetext{
* Associate Dean for Faculty and Research, John E. Cribbet Professor of Law, and Professor of Philosophy, University of Illinois. This Article was prepared for this Symposium after the Conference on Originalism held at the Northwestern University School of Law on April 24, 2008. The paper presented at that conference was Lawrence B. Solum, Semantic Originalism (Illinois Pub. Law Research Paper No. 07-24, 2008), available at http://ssrn.com/abstract=1120244. I owe thanks to William Baude for comments on an earlier draft of this Article. (c) 2009 by the Author. Permission is hereby granted to duplicate this paper for scholarly or teaching purposes, including permission to reproduce multiple copies or post on the Internet for classroom or other scholarly use and to quote extended passages in scholarly work, subject only to the requirement that this copyright notice, the title of the article, the name of the author, and citation to the Northwestern University Law Review be prominently included in the copy or extended excerpt. Permission is hereby granted to use short excerpts (500 words or less each, so long as the total word count of the excerpts does not exceed $50 \%$ of the total word count of this work) with an appropriate citation and without inclusion of a copyright notice. In the event of the death or permanent incapacity of the author, all claims to copyright in the work are relinquished and the work is dedicated to the public domain in perpetuity. Even if the author is then living, all copyright claims are relinquished as of January 1, 2050. In the event that the relinquishment of copyright is not given legal effect, an unlimited license of all rights to all persons for all purposes is granted as of that date.
} 
C. Instrumentalism and Formalism in Constitutional Theory.......................... 958

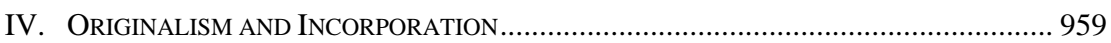

A. Heller's Dictum on Incorporation ................................................................... 960

B. Privileges or Immunities Versus Due Process ............................................ 961

C. Implications of Incorporation for Originalism and Stare Decisis............... 962

D. Privileges or Immunities and Original Public Meaning .............................. 964

E. Privileges or Immunities and Unenumerated Rights................................. 970

V. HELLER AND the INTERPRETATION-CONSTRUCtion DiSTINCTION ......................... 971

A. $\quad$ The Puzzling Passage in Heller.................................................................. 972

B. Two Distinctions: Interpretation-Construction and Ambiguity-Vagueness. 973

C. Interpretation in Heller ................................................................................. 975

D. Construction in Heller................................................................................. 975

E. Construction and the Disagreements Between Justice Scalia and Justice

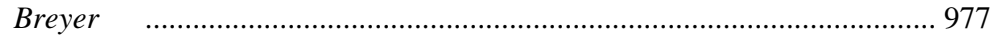

F. The Role of Constitutional Construction in the Future of the Second

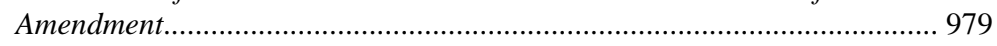

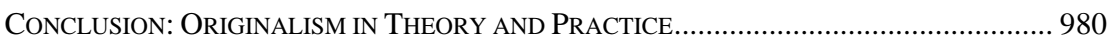

INTRODUCTION: THE EXEMPLARY SIGNIFICANCE OF HELLER

On June 26, 2008, the United States Supreme Court handed down its 5-4 decision in District of Columbia v. Heller, ${ }^{1}$ striking down a District of Columbia statute that prohibits the possession of useable handguns in the home $^{2}$ on the ground that it violated the Second Amendment. ${ }^{3}$ Justice Scalia's majority opinion drew dissents from Justice Stevens ${ }^{4}$ and Justice Breyer. ${ }^{5}$ Collectively, the opinions in Heller represent the most important and extensive debate on the role of original meaning in constitutional interpretation among the members of the contemporary Supreme Court. ${ }^{6}$

\footnotetext{
128 S. Ct. 2783 (2008).

2 Id. at 2788, 2821-22.

${ }^{3}$ U.S. CONST. amend. II.

${ }^{4}$ Heller, 128 S. Ct. at 2822 (Stevens, J., dissenting). Stevens was joined by Justices Souter, Ginsburg, and Breyer. Id.

${ }^{5}$ Id. at 2847 (Breyer, J., dissenting). Breyer was joined by Justices Stevens, Ginsburg, and Breyer.

${ }^{6}$ Subsequent to the composition of this Article, a variety of published work has analyzed the Heller opinion from several different perspectives. See Akhil Reed Amar, Heller, HLR, and Holistic Legal Reasoning, 122 HARV. L. REV. 145 (2008); Carl T. Bogus, Heller and Insurrectionism, 59 SYRACUSE L. REV. 253 (2008); Alan E. Brownstein, The Constitutionalization of Self-Defense in Tort and Criminal Law, Grammatically Correct Originalism, and Other Second Amendment Musings, 60 Hastings L.J. (forthcoming June 2009); Maxine Burkett, Much Ado About . . Something Else: D.C. v. Heller, The Racialized Mythology of the Second Amendment, and Gun Policy Reform, 12 J. GENDER RACE \& JUST. 57 (2008); Saul Cornell, Originalism on Trial: The Use and Abuse of History in District of Columbia v. Heller, 69 OHIO ST. L.J. 625 (2008); Brannon P. Denning, The New Doctrinalism in Constitutional Scholarship and District of Columbia v. Heller, 75 TENN. L. REv. 789 (2008) [hereinafter Denning, The New Doctrinalism]; Brannon P. Denning \& Glenn Harlan Reynolds, Five Takes on District of Columbia v. Heller, 69 Oнiо ST. L. J. 671 (2008); Michael C. Dorf, Does Heller Protect a Right to Carry Guns
} Id. 
Prior to Heller, the Court squarely addressed the substantive meaning of the Second Amendment on only one prior occasion. The 1939 decision of United States v. Miller ${ }^{7}$ considered the meaning of the "right to keep and bear arms." The Miller Court held that "federal convictions for transporting an unregistered short-barreled shotgun in interstate commerce" ${ }^{8}$ were not invalidated by the Second Amendment absent a demonstration on the record that possession of this type of weapon "has some reasonable relationship to the preservation or efficiency of a well regulated militia . . ..” There are instances in which the Court has resolved issues regarding the Second Amendment without interpreting the meaning of the key phrase: "the right to keep and bear arms." In 1876, the Court had held that the Second Amendment applied only to action by Congress, and hence did not apply to the states: ${ }^{10}$ subsequent decisions in $1886^{11}$ and in $1894^{12}$ reaffirmed that holding. Given the sparse precedent, Heller offered an opportunity that is rare in contemporary constitutional jurisprudence: the Justices were asked to write on a slate that was almost clean.

In a typical constitutional case in the twenty-first century, the Court must deal with a plethora of probative precedent. In Heller, however, there was only a single case that addressed the meaning of the Second Amendment, and the holding of that case was clearly distinguishable in the eyes of the majority. ${ }^{13}$ Given the absence of constraining precedent, Heller has ex-

Outside the Home?, 59 SYRACUSE L. REV. 225 (2008); Richard A. Epstein, A Structural Interpretation of the Second Amendment: Why Heller Is (Probably) Wrong on Originalist Grounds, 59 SYRACUSE L. REV. 171 (2008); David B. Kopel, The Natural Right of Self-Defense: Heller's Lesson for the World, 59 SYRACUSE L. REV. 235 (2008); Sanford Levinson, United States: Assessing Heller, 7 INT’L J. CONST. L. 316 (2009); Clark Neily, District of Columbia v. Heller: The Second Amendment Is Back, Baby, 2008 Cato Sup. Ct. Rev. 127; Michael P. O’Shea, The Right to Defensive Arms After District of Columbia v. Heller, 111 W. VA. L. REV. 349 (2009); Glenn H. Reynolds \& Brannon P. Denning, Human Rights and Globalization: Putting the Race to the Top in Perspective, 102 Nw. U. L. REV. 2035 (2008); Richard Schragger, The Last Progressive: Justice Breyer, Heller, and "Judicial Judgment", 59 SYRACuse L. ReV. 283 (2008); Reva B. Siegel, Dead or Alive: Originalism as Popular Constitutionalism in Heller, 122 HARV. L. REV. 191 (2008); Cass R. Sunstein, Second Amendment Minimalism: Heller as Griswold, 122 HARV. L. Rev. 246 (2008); Mark Tushnet, Heller and the New Originalism, 69 OHIO ST. L.J. 609 (2008); J. Harvie Wilkinson III, Of Guns, Abortion, and the Unraveling Rule of Law, 95 VA. L. REV. (forthcoming 2009), available at http:// papers.ssrn.com/sol3/papers.cfm?abstract_id=1265118; David C. Williams, Death to Tyrants: District of Columbia v. Heller and the Uses of Guns, 69 OHIO ST. L.J. 641 (2008); Richard Posner, In Defense of Looseness, THE NEw RePublic, Aug. 27, 2008, available at http://www.tnr.com/story_print.html?id=d2f38db8-3c8a-477e-bd0a-5bd56de0e7c0; Glenn H. Reynolds \& Brannon P. Denning, Heller's Future in the Lower Courts, 102 Nw. U. L. REV. ColLoQUY 406 (2008), http://www.law.northwestern.edu/lawreview/colloquy/2008/23.

7307 U.S. 174 (1939).

${ }^{8}$ Heller, 128 S. Ct. at 2814.

${ }^{9}$ Miller, 307 U.S. at 178.

${ }^{10}$ United States v. Cruikshank, 92 U.S. 542, 553 (1876).

11 Presser v. Illinois, 116 U.S. 252, 264-65 (1886).

12 Miller v. Texas, 153 U.S. 535, 538 (1894).

13 Heller, 128 S. Ct. at 2814 ("Miller stands only for the proposition that the Second Amendment right, whatever its nature, extends only to certain types of weapons.”). 
emplary significance for investigations of the relationship between constitutional theory and constitutional practice by squarely posing the following question: How should courts determine the meaning of the Constitution when they address an interpretive question in the first instance?

Writing for the Heller majority, Justice Scalia addressed the issue of constitutional method as follows:

The Second Amendment provides: “A well regulated Militia, being necessary to the security of a free State, the right of the people to keep and bear Arms, shall not be infringed." In interpreting this text, we are guided by the principle that " $[\mathrm{t}]$ he Constitution was written to be understood by the voters; its words and phrases were used in their normal and ordinary as distinguished from technical meaning." Normal meaning may of course include an idiomatic meaning, but it excludes secret or technical meanings that would not have been known to ordinary citizens in the founding generation. ${ }^{14}$

In this passage, the Court embraced originalism-the theory that "original meaning" should guide interpretation of the Constitution. In particular, the Court embraced what has been called "original public meaning originalism" - the view that the original meaning of a constitutional provision is the conventional semantic meaning that the words and phrases had at the time the provision was framed and ratified.

This Article investigates the relationship between originalist constitutional theory and judicial practice in the context of the Supreme Court's decision in District of Columbia v. Heller. Part I contextualizes Heller by tracing the evolution of contemporary originalist theory. Part II examines the reasoning of the Heller majority and identifies the unarticulated assumptions that would be required to square the result in Heller with a fully articulated originalist theory of constitutional interpretation. Part III examines the role of intentionalist and teleological reasoning in Justice Stevens's dissenting opinion. Part IV considers the implications of Heller's originalist theory for the question whether the Second Amendment will be applied to the states via the Due Process Clause or the Privileges or Immunities Clause of the Fourteenth Amendment. Part V considers how the Heller decision bears on the distinction between constitutional interpretation and constitutional construction that has emerged from contemporary originalist theory. Finally, the Article concludes with some brief observations about the implications of Heller on the relationship between originalist theory and originalist practice.

\section{HELLER AND THE EVOLUTION OF CONTEMPORARY ORIGINALIST THEORY}

What is the relationship between the majority opinion in Heller and contemporary theoretical debates about originalism? The intellectual his-

${ }^{14}$ Id. at 2788 (citations omitted). 
tory of contemporary constitutional originalism is long and complex, and a thorough account would require a long monograph. ${ }^{15}$ Nonetheless, Heller can be illuminated by situating the disagreements among the Justices in the context of the evolution of contemporary originalist theory. The sketch of that history offered here is limited to recent constitutional theory; it ignores the prehistory of what we might call the "contemporary originalism debates,” debates over original meaning amongst judges, politicians, and scholars that predate the 1970 s. $^{16}$

\section{A. Original Intentions of the Framers}

Contemporary debates about originalism trace back to the early 1970s. In 1971, Robert Bork wrote Neutral Principles and Some First Amendment Problems,${ }^{17}$ an article that is sometimes considered the opening move in the development of contemporary originalist theory. In 1976, then-Associate Justice William Rehnquist authored The Notion of a Living Constitution, which, based on the writings of the Framers, explicitly criticized living constitutionalism and implicitly endorsed originalism. ${ }^{18}$ A year later, in 1977, Raoul Berger penned Government by Judiciary, ${ }^{19}$ which argued that the Supreme Court's interpretations of the Fourteenth Amendment were contrary to the original intentions of its Framers. In 1985, then-Attorney General Edwin Meese put originalism on the political agenda in a well-publicized

\footnotetext{
${ }^{15}$ For a different view from an earlier time, see Daniel A. Farber, The Originalism Debate: A Guide for the Perplexed, 49 OHIO ST. L.J. 1085, 1085 (1989) (offering a concise "tourist guide" introduction to the "original intent" debate).

16 Although the first appearance of the term "originalism" in the Westlaw JLR database is in Paul Brest, The Fundamental Rights Controversy: The Essential Contradictions of Normative Constitutional Scholarship, 90 YALE L.J. 1063, 1090 (1981), scholarly usage of related phrases extends at least as far back as the 1930s. The phrase "original meaning" was used in the constitutional context in Edwin Borchard, The Supreme Court and Private Rights, 47 YALE L.J. 1051, 1063 (1938) ("There would be far greater advantage in restoring the original meaning of the 'privileges and immunities' clause and by the process of inclusion and exclusion letting the country know what are now federal privileges, than in forcing the court to draw upon the fathomless depths of the 'due process' clause to give effect to their personal convictions of economic and social propriety.”). The phrase "original intentions" appears in Howard Jay Graham, The "Conspiracy Theory" of the Fourteenth Amendment, 48 YALE L. J. 171, 18990 (1938) ("Wholly apart from Bingham's personal understanding of his phraseology, his original intentions in drafting it, or the relations existing between the Cleveland and Mahoning Railroad and other members of the Joint Committee, it is possible that Reverdy Johnson, in the course of the Committee's deliberations, or perhaps even in private conversation with Conkling, mentioned Justice Grier's decision as among the most recent involving the due process clause, and in this manner precipitated a frank discussion of the entire problem of corporate rights." (citation omitted)). The phrase "original understanding" appears in Charles Fairman, Does the Fourteenth Amendment Incorporate the Bill of Rights?: The Original Understanding, 2 STAN. L. REV. 5, 5 (1949) (exploring the meaning of the Fourteenth Amendment's clauses "at the time the Amendment was adopted").

17 Robert H. Bork, Neutral Principles and Some First Amendment Problems, 47 IND. L.J. 1 (1971).

${ }^{18}$ William H. Rehnquist, The Notion of a Living Constitution, 54 TEx. L. REv. 693, 706 (1976).

19 RAOUl BERgER, GOVERNMENT BY Judiciary (1977).
} 
speech before the American Bar Association. ${ }^{20}$ Meese's speech included the following passage:

In reviewing a term of the Court, it is important to take a moment and reflect upon the proper role of the Supreme Court in our constitutional system. The intended role of the judiciary generally and the Supreme Court in particular was to serve as the "bulwarks of a limited constitution." The judges, the Founders believed, would not fail to regard the Constitution as "fundamental law" and would "regulate their decisions" by it. As the "faithful guardians of the Constitution," the judges were expected to resist any political effort to depart from the literal provisions of the Constitution. The text of the document and the original intention of those who framed it would be the judicial standard in giving effect to the Constitution. ${ }^{21}$

Bork, Rehnquist, Berger, and Meese implicitly endorsed what we now call "original intentions originalism," the view that the original intentions of the Framers should guide constitutional interpretation.

\section{B. The Misconceived Quest and the Original Understanding of Original Intentions}

Following Berger's book, but five years before Meese's speech, Paul Brest wrote The Misconceived Quest for the Original Understanding, ${ }^{22}$ one of the most cited articles on constitutional theory. ${ }^{23}$ Brest's article advanced a variety of criticisms of original intentions originalism, including: (1) the difficulty of ascertaining the institutional intention of a multimember body in general; ${ }^{24}(2)$ the particular problems associated with identifying the intention of the members of Philadelphia Convention and the various state ratifying conventions in the case of the original Constitution and of Congress and the various state legislatures in the case of amendments; ${ }^{25}$ (3) the problem of determining the level of generality or specificity of the Framers' and ratifiers' intentions; ${ }^{26}(4)$ the problem of inferring intentions from constitutional structure ${ }^{27}(5)$ the difficulty of translating the Framers' and rati-

\footnotetext{
20 See Edwin Meese III, Speech Before the American Bar Association (July 9, 1985), reprinted in The Great Debate: InTERPReting OuR WritTEn Constitution (Paul G. Cassel ed., 1986), available at http://www.fed-soc.org/resources/id.49/default.asp; see also Edwin Meese III, The Case for Originalism, THE HERITAGe Foundation, June 6, 2005, http://www.heritage.org/Press/Commentary/ ed060605a.cfm; Lynette Clemetson, Meese's Influence Looms in Today's Judicial Wars, N.Y. TIMES, Apr. 17, 2005, at A1.

${ }^{21}$ Meese, Speech Before the American Bar Association, supra note 20.

22 Paul Brest, The Misconceived Quest for the Original Understanding, 60 B.U. L. REV. 204 (1980).

${ }^{23}$ A Westlaw search of the JLR database for the string corresponding to the title yielded 719 hits on November 10, 2008.

24 Brest, supra note 22, at 214.

${ }^{25} \mathrm{Id}$. at 214-15.

${ }^{26} \mathrm{Id}$. at 216-17.

${ }^{27}$ Id. at 217-18.
} 
fiers' beliefs and values given changes in circumstances over time, ${ }^{28}(6)$ the problem of the democratic legitimacy-i.e., that the Constitution of 1789 was drafted and ratified without the participation of women and slaves; ${ }^{29}$ and (7) the problem of instability, in that an inflexible constitutional order cannot adapt to changing circumstances. ${ }^{30}$ Brest had much more to say, and there were many other critics of originalism, but this list is sufficient to illustrate the reception that originalism received from constitutional theorists in the late 1970s and early 1980s.

Brest also raised the problem of the Framers' and ratifiers' interpretive intentions, ${ }^{31}$ and his remarks anticipated Jefferson Powell's 1985 article, The Original Understanding of Original Intent. ${ }^{32}$ Powell's article interrogated the assumption that original intentions originalists believed that the Framers' themselves expected that the Constitution would be interpreted to conform to their intentions. Although Powell conceded that there were references to "original intention" and "intent of the framers" in the constitutional discourse of the Founding era, he argued that those phrases did not represent an early version of original intentions originalism. Instead, he argued that “[t]he Philadelphia framers' primary expectation regarding constitutional interpretation was that the Constitution, like any other legal document, would be interpreted in accord with its express language.,"33 Both the evidence for Powell's thesis and its implications are controversial, but its effect on scholarly opinion was profound. The strongest implication of the article is that original intentions originalism is a self-effacing theory because it requires that the Framers' intentions regarding interpretation be respected, but those intentions require that the Framers' intentions be disregarded.

Brest and Powell were hardly the only critics of original intentions originalism, but their arguments, combined with others, helped form the scholarly consensus of the era. ${ }^{34}$ Essentially, that consensus claimed that the original intentions of the Framers could not serve as the basis for a viable theory of constitutional interpretation and construction.

${ }^{28}$ Id. at $219-22$.

${ }^{29} \mathrm{Id}$. at 230.

${ }^{30} \mathrm{Id}$. at 231 .

${ }^{31}$ Id. at $215-16$.

${ }^{32}$ H. Jefferson Powell, The Original Understanding of Original Intent, 98 HARV. L. REV. 885 (1985).

${ }^{33} I d$. at 903.

34 This is not an intellectual history of the originalism debates, and I am not claiming that either Brest or Powell articulated the first or best version of the claims they made. No string cite can do justice to the literature. There were many influential critics of original intentions originalism; one of the most important was Ronald Dworkin. See Ronald Dworkin, The Forum of Principle, 56 N.Y.U. L. REV. 469, 470 (1981). 


\section{Original Understanding of the Ratifiers}

During this period, the originalism debate took a brief detour into a variant of original intentions originalism that emphasized the understandings $^{35}$ or intentions of the ratifiers - either the state ratifying conventions understood as corporate bodies or of the individuals who attended the ratifying conventions and voted in favor of ratification. ${ }^{36}$

We need not tarry long over this twist in the debate. The move to ratifiers' understanding or intent is best understood in conjunction with popular sovereignty as a justification for originalism. The ratifiers, rather than the Framers, could plausibly be viewed as expressing the political will of "We the People." However, all of the problems that attended the equation of constitutional meaning with Framers' intent seem to attach to ratifiers' intent. Moreover, evidence may be even more difficult to obtain ${ }^{37}$ and the problems of group intention-of multiple conventions with multiple members-even more confounding with respect to ratifiers' intent. To the extent that the ratifiers' understanding is rooted in the public meaning, the emphasis on ratifiers is merely a way station on the journey from original intentions to original public meaning. ${ }^{38}$

\section{We the People}

The year before Meese gave his speech to the American Bar Association and Jefferson Powell wrote about the original understanding of original intent, Bruce Ackerman delivered his Storrs Lectures, entitled Discovering

\footnotetext{
35 See Richard H. Fallon, Jr., Judicially Manageable Standards and Constitutional Meaning, 119 HARV. L. REV. 1275, 1317 (1996) (defining “originalism" as "the theory that the original understanding of those who wrote and ratified various constitutional provisions determines their current meaning”).

36 See Charles A. Miller, The Supreme Court And the Uses of History 157-58 (1969) (arguing that originalism should look to the intent of the ratifiers as well as of the Framers); see also Charles A. Lofgren, The Original Understanding of Original Intent, 5 Const. Comment. 77, 113 (1988) ("Indeed, it is not too much to say that at least some of the founders saw the ratifiers' historical or subjective intent as a check on constructions which cut loose from the original understandings of the sovereign people.”).

37 See Henry P. Monaghan, Our Perfect Constitution, 56 N.Y.U. L. REV. 353, 375 n.130 (1981) ("Although the intention of the ratifiers, not the Framers, is in principle decisive, the difficulties of ascertaining the intent of the ratifiers leaves little choice but to accept the intent of the Framers as a fair reflection of it.”).

38 Similar points could be made about what might be called "popular meaning," the view that the relevant intentions or understandings should be those of "We the People" or the popular sovereign- the relevant actor for popular constitutionalism. If the relevant intentions are those of each and every citizen, then popular constitutionalism suffers from compounded versions of the ills that afflict intentionalism. If popular constitutionalism points to public meaning, then it is simply another version of originalmeaning originalism. For discussion of popular constitutionalism, see LARRY KrAMER, THE PEOPLE THEMSElves: PopUlar Constitutionalism AND Judicial REVIEW (2004); see also Larry Alexander \& Lawrence B. Solum, Popular? Constitutionalism?, 118 HARV. L. Rev. 1594 (2005) (book review).
} 
the Constitution, at Yale Law School. ${ }^{39}$ It was in these lectures that Ackerman's theory of constitutional politics made its first wide impression on the community of constitutional scholars. Ackerman's theory distinguishes ordinary politics-what happens when state legislatures and Congress enact statutes, for example-from constitutional politics. Here is the very first statement of Ackerman's view, dualism, in the second lecture:

[T] he Federalist elaborates a dualistic conception of political life. One form of political action-I shall call it constitutional politics-is characterized by Publian appeals to the common good, ratified by a mobilized mass of American citizens expressing their assent through extraordinary institutional forms. Although constitutional politics is the highest kind of politics, it should be permitted to dominate the nation's life only during rare periods of heightened political consciousness. During the long periods between these constitutional moments, a second form of activity-I shall call it normal politics—prevails. Here, factions try to manipulate the constitutional forms of political life to pursue their own narrow interests. Normal politics must be tolerated in the name of individual liberty; it is, however, democratically inferior to the intermittent and irregular politics of public virtue associated with moments of constitutional creation. ${ }^{40}$

Ackerman's theory served as an answer to Alexander Bickel's countermajoritarian difficulty: the problem of democratic legitimacy that attends judicial review by unelected judges ${ }^{41}$ Judges as faithful agents of the "We the People," who legislate in rare constitutional moments - or later "periods"-act more democratically than do legislators, who serve special interests and escape the people's attention during the extended periods of ordinary politics.

As told in the Storrs Lectures, Ackerman's theory focused on three constitutional moments: the Founding (the Constitution of 1789), Reconstruction (the Thirteenth, Fourteenth, and Fifteenth Amendments), and the New Deal. Here is the initial appearance of that idea in the lectures:

Speaking schematically, this historical story is dominated by three peaks of high importance that tower over valleys full of more particular meanings. The first peak, of course, is the Founding itself: the framing of the original Constitution and the Bill of Rights, Marbury v. Madison and McCulloch v. Maryland. The second peak is constituted by the legal events surrounding the Civil War: the judicial failure in Dred Scott and the constitutional affirmations of the Civil War Amendments. The third peak centers around the legitimation of the activist welfare state: the long Progressive struggle against judicial resistance and

39 Bruce A. Ackerman, The Storrs Lectures: Discovering the Constitution, 93 YALE L.J. 1013 (1984).

${ }^{40}$ Id. at 1022-23 (citations omitted).

41 See generally AleXANDER M. Bickel, THE LEASt DANGERous Branch: THE Supreme CourT AT THE BAR of Politics (1962); see also THE JUdiciary AND AMERICAN DEMOCRACY: AlEXANDER BICKEL, THE COUNTERMAJORITARIAN DIFFICULTY AND CONTEMPORARY CONSTITUTIONAL THEORY (Kenneth D. Ward \& Cecilia R. Castillo eds., 2005). 
the dramatic capitulation by the Old Court before the New Deal in 1937. Time and again, we return to these moments; the lessons we learn from them control the meanings we give to our present constitutional predicaments. ${ }^{42}$

Because Ackerman's theory purported to legitimize progressive New Deal constitutionalism, his view might have been construed as the polar opposite of originalism, but at a deep level, Ackerman's theory seemed to require an account of original meaning. Without employing original meaning, judicial enforcement of the Constitution could not be legitimized by democratic constitutional politics. In other words, a theory of original meaning is required for constitutional content to be determined by "We the People."

Ackerman's development of popular sovereignty theory has been extraordinarily influential, and others have contributed important work in this vein, ${ }^{43}$ prominently Akhil Reed Amar, ${ }^{44}$ Ackerman's colleague at Yale Law School. Amar's position was described by Cass Sunstein in the following terms:

[I]n the law schools the most influential originalist may be Akhil Reed Amar, an ingenious and prolific scholar at Yale Law School. Describing himself as a "textualist" who is interested in history, Amar is methodologically quite close to Scalia. He is intensely interested in the text and in the historical record, and he is generally searching for the original meaning of contested terms. Amar wishes to know what the Constitution "really means," and he puts that question as if it were largely or entirely a matter of excavation. ${ }^{45}$

Although Sunstein's interpretation of Amar is surely plausible, characterizing Ackerman and Amar's theoretical position in originalist terms is problematic, in no small part because they both eschew explicit theorizing about constitutional interpretation. Nevertheless, even if Ackerman and Amar do not describe their views as originalist, it is clear that their approaches to the Constitution, which emphasize popular sovereignty and the constitutional text, have had both direct and indirect influences over contemporary theoretical debates explicitly concerned with originalism. ${ }^{46}$

42 Ackerman, supra note 39, at 1051-52.

43 See, e.g., Kurt T. Lash, A Textual-Historical Theory of the Ninth Amendment, 60 STAN. L. REV. 895 (2007); Kurt T. Lash, Originalism, Popular Sovereignty, and Reverse Stare Decisis, 93 VA. L. REV. 1437 (2007).

44 See AKhil Reed Amar, America’s Constitution: A Biography (2005); AKhil ReEd Amar, THE BILL OF RIGHTS (1998).

${ }^{45}$ Cass R. Sunstein, Originalism for Liberals, THE NEW RePUBLIC, Sept. 28, 1998, at 31, available at http://home.uchicago.edu/ csunstei/originalism.html (reviewing AMAR, THE BILL OF RIGHTS, supra note 43, and AKHIL ReEd AMAR \& Alan Hirsch, For the PEOPLE (1998)).

46 Thus, it is no accident that Amar and Ackerman's students describe themselves as originalists. See, e.g., Kurt T. Lash, A Textual-Historical Theory of the Ninth Amendment, supra note 43, at 900 ("I will consider the historical record and attempt to identify which of the possible textual meanings are more or less plausible, given historical evidence of original public understanding. In this way, I hope to provide an account of the Ninth Amendment satisfactory in terms of both originalism and textualism.”). 


\section{E. Original Public Meaning and the New Originalism}

This sets the stage for what is sometimes called "the New Originalism" ${ }^{47}$ and is also labeled "Original Public Meaning Originalism." ${ }^{48}$ Whatever the actual origins of this theory, the conventional story identifies Antonin Scalia as having a key role. As early as 1986, Scalia gave a speech exhorting originalists to "change the label from the Doctrine of Original Intent to the Doctrine of Original Meaning." ${ }^{9}$ The phrase "original public meaning" seems to have entered the contemporary theoretical debates through the work of Gary Lawson, ${ }^{50}$ with Steven Calabresi as another "early adopter." ${ }^{51}$ The core idea of the revised theory is that the original meaning of the Constitution is the original public meaning of the constitutional text.

Randy Barnett ${ }^{52}$ and Keith Whittington ${ }^{53}$ have played prominent roles in the development of the "New Originalism." Both Barnett and Whittington base their theories on a foundation of "original public meaning," but they build upon the views of Scalia and Lawson in a variety of interesting ways. For the purposes of this very brief survey, perhaps their most important move is to embrace the distinction between "constitutional interpretation," understood as the enterprise of discerning the semantic content of the Constitution, and "constitutional construction," which we might tentatively define as the activity of further specifying constitutional rules when the original public meaning of the text is vague or underdeterminate. ${ }^{54}$ This distinction explicitly acknowledges what we might call the fact of constitutional underdeterminacy. ${ }^{55}$ With this turn, original-meaning originalists ex-

47 See, e.g., Keith Whittington, The New Originalism, 2 GEO. J.L. \& PUB. POL’Y 599 (2004).

48 See, e.g., Randy E. Barnett, An Originalism for Nonoriginalists, 45 LOY. L. REV. 611 (1999).

49 Antonin Scalia, Address Before the Attorney General's Conference on Economic Liberties in Washington, D.C. (June 14, 1986), in ORIGINAL MEANING JURISPRUDENCE: A SOURCEBOOK 101, 106 (U.S. Dep't of Justice ed., 1987); see also Caleb Nelson, Originalism and Interpretive Conventions, 70 U. CHI. L. REV. 519, 554-55 (2003) (noting that most originalists have accepted Justice Scalia’s suggestion).

50 See Gary Lawson, Proving the Law, 86 Nw. U. L. REv. 859, 875 (1992). For extended discussions of "original public meaning," see Vasan Kesavan \& Michael Stokes Paulson, The Interpretive Force of the Constitution's Secret Drafting History, 91 GEO. L.J. 1113, 1127 (2003); Samuel T. Morison, The Crooked Timber of Liberal Democracy, 2005 Mich. ST. L. REV. 461, 465.

51 See Steven G. Calabresi \& Saikrishna B. Prakash, The President's Power to Execute the Laws, 104 YALE L.J. 541, 553 (1994).

52 See RANDY E. BARNETT, RESTORING THE LOST CONSTITUTION (2004).

53 See Keith E. Whittington, Constitutional Construction (1999); Keith E. Whittington, CONSTITUTIONAL INTERPRETATION (1999).

54 Another important early adopter of this distinction (in the context of constitutional theory) was Robert Clinton. See Robert N. Clinton, Original Understanding, Legal Realism, and the Interpretation of "This Constitution," 72 Iowa L. REV. 1177 (1987).

${ }^{55}$ See Lawrence B. Solum, Semantic and Normative Originalism: Comments on Brian Leiter's “Justifying Originalism," Legal Theory Blog, Oct. 30, 2007, http://lsolum.typepad.com/ legaltheory/2007/10/semantic-and-no.html (observing that conventional semantic meaning of a text can underdetermine its application in several ways); cf. Lawrence B. Solum, On the Indeterminacy Crisis: 
plicitly embrace the idea that when the original public meaning of the text "runs out," application of the linguistic meaning of the constitutional case to a particular dispute must be guided by something other than original meaning.

Once originalist theory (in some important instantiations) had acknowledged that vague constitutional provisions required construction, this step opened the door for reconciliation between originalism and living constitutionalism. The key figure in that reconciliation has been Jack Balkin through his influential 2006 and 2007 essays Abortion and Original Meaning $^{56}$ and Original Meaning and Constitutional Redemption. ${ }^{57}$ In these essays, Balkin argued for a reconciliation of original-meaning originalism with living constitutionalism according to a theory that might be called "the method of text and principle." The meaning of the "text" provides a constraining framework within which constitutional "principles" operate. One understanding of Balkin's view is that the "text" requires interpretation and the "principles" are matters of constitutional construction.

Predating much of the American work on the New Originalism was Jeffrey Goldsworthy's work, addressing the Australian Constitution, but developed with an explicit awareness of the theoretical debates swirling around American constitutionalism. Goldsworthy's first major statement, Originalism in Constitutional Interpretation, ${ }^{58}$ was published in an Australian law review in 1997. As Goldsworthy's work illustrates, innovations in American constitutional theory may have been anticipated elsewhere and American theorists have no monopoly on the creation of new (or the resurrection of old) theoretical constructs.

\section{F. Original Applications and Original Methods}

Two very recent ideas deserve particular mention: "original applications" and "original methods." The phrase "original applications" or "original expected applications" seems to originate with Jack Balkin, ${ }^{59}$ but Mark Greenberg and Harry Litman articulated a similar distinction between "original meaning” and "original practices" in their important 1998 article,

Critiquing Critical Dogma, 54 U. CHI. L. REv. 462 (1987) (distinguishing determinacy, indeterminacy, and underdeterminacy).

56 Jack M. Balkin, Abortion and Original Meaning, 24 CONST. COMMENT. 291 (2007).

57 Jack M. Balkin, Original Meaning and Constitutional Redemption, 24 CONST. COMMENT. 427 (2007)..

58 Jeffrey Goldsworthy, Originalism in Constitutional Interpretation, 25 FED. L. REV. 1 (1997); see also Lawrence B. Solum, Goldsworthy on the New Originalism, Legal Theory Blog, Nov. 2, 2007, http://lsolum.typepad.com/legaltheory/2007/11/goldsworthy-on-.html.

59 See Jack M. Balkin, Abortion and Original Meaning, supra note 56, at 293; Jack Balkin, Original Meaning and Constitutional Redemption, supra note 57; Jack Balkin, Alive and Kicking: Why No One Truly Believes in a Dead Constitution, SLATE, Aug. 29, 2005, http://www.slate.com/id/2125226/; Jack Balkin, Clarence Thomas's Originalism, Balkinization, July 11, 2007, http://balkin.blogspot.com/ 2007/07/clarence-thomass-originalism.html. 
The Meaning of Original Meaning. ${ }^{60}$ Although Greenberg and Litman deserve the credit for the deepest and most thorough discussion of the issues, my account here will focus on Balkin's formulation, which brings the idea of original expected applications into the New Originalism, not as a component but rather by way of exclusion. Greenberg and Litman saw their point primarily as a criticism of originalism; Balkin sees the same issue, but concludes that originalism is strengthened by excluding "original expected applications." 61

The distinction is a simple one. The linguistic meaning of a text is one thing, and expectations about the application of that meaning to future cases are a different thing. Balkin makes use of the distinction to argue that some originalists have conflated meaning with expected applications:

Originalists generally assume that if we do not apply the constitutional text in the way it was originally understood at the time of its adoption we are not following what the words mean and so will not be faithful to the Constitution as law. But they have tended to conflate two different ideas-the expected application of constitutional texts, which is not binding law, and the original meaning, which is. Indeed, many originalists who claim to be interested only in original meaning, like Justice Antonin Scalia, have encouraged this conflation of original meaning and original expected application in their practices of argument. $^{62}$

The fact that original expected applications are distinct from original meanings should not imply that the two are unrelated. Expected applications of a text may offer evidence about its meanings, even if these applications are neither decisive evidence of meaning nor meaning itself.

Of course, some originalists may contest Balkin's move and argue that original expectations originalism is viable. The justification could be that reliance on original expectations is the distinctive characteristic that marks originalist theories as originalist. ${ }^{63}$ But this view appears incorrect given the history of originalist thought, and it is certainly contrary to the theories of New Originalists like Balkin, Barnett, and Whittington.

Another very recent development is the emergence of what might be called "original methods originalism," the view that the original meaning of the Constitution includes the methods of interpretation that the Framers, ratifiers, and/or public of the Founding era could, would, or should have

\footnotetext{
${ }^{60}$ Mark D. Greenberg \& Harry Litman, The Meaning of Original Meaning, 86 GEO. L.J. 569 (1998).

61 Balkin, Original Meaning and Constitutional Redemption, supra note 59, at 446.

62 Balkin, supra note 56, at 292-93.

63 Cf. Christopher L. EISGRUber, CONSTITUtional SElf-GovernMENT 25-26 (2001) (characterizing originalism as relying on original expectations).
} 
expected to guide constitutional practice. This view is strongly associated with Michael Rappaport and John McGinnis. ${ }^{64}$ They write:

[T] he focus of originalism should be on how a reasonable person at the time of the Constitution's adoption would have understand its words and thought they should be interpreted. The Constitution's provisions were based on commonly accepted meanings and the interpretative rules of the time. Some of the provisions had clear meanings. Others may have seemed ambiguous, but the enactors would have believed that their future application would be based [on] the interpretive rules accepted at the time. Thus, their assessment of the meaning and the desirability of the Constitution would depend on the interpretive rules that they thought would apply. ${ }^{65}$

We can call this approach "original methods originalism," reflecting its commitment to the methods of interpretation that characterized the Founding era. Notice that McGinnis and Rappaport's formulation of their idea does not embrace the distinction between interpretation and construction in the Whittington/Barnett sense. ${ }^{66}$

In a different vein, an important contribution to understanding the implications of the New Originalism appeared in an important 2006 article by Richard Fallon, titled Judicially Manageable Standards and Constitutional Meaning. ${ }^{67}$ Fallon does not embrace originalism, but he identified the key distinction between the meaning of the Constitution (its semantic content) and implementing rules of constitutional law (legal content):

Despite large apparent differences between originalism and nonoriginalist theories, originalist and nonoriginalist judges converge in their decisions surprisingly often. Given the strident debates among constitutional theorists, one well might wonder how so much agreement could eventuate. The reason, I would suggest, is that what we call constitutional theories or theories of constitutional interpretation are often theories about constitutional meaning that implicitly accept the permissibility of a disparity between constitutional meaning and implementing doctrine. If constitutional theories fix the meaning of the Constitution, but stipulate that implementing doctrines sometimes permissibly diverge from it, then such theories are less complete and thus less practically significant than their proponents suggest. ${ }^{68}$

\footnotetext{
${ }^{64}$ Their view is briefly stated in John O. McGinnis \& Michael B. Rappaport, Original Interpretive Principles as the Core of Originalism, 24 CONST. COMMENT 371 (2007).

${ }^{65}$ Id. at 3.

66 To the extent that McGinnis and Rappaport believe that original methods recover the linguistic meaning or semantic content of the constitutional text, their theory faces severe obstacles. The public linguistic meaning of a text cannot be the legal construction that is placed upon that text by legal interpreters. Legal methods operate on the semantic content fixed by linguistic meaning: they do not create it. To think otherwise is to confuse meaning in the semantic sense with meaning in the applicative sense. See Lawrence B. Solum, Semantic Originalism (Illinois Pub. Law Research Paper No. 07-24, 2008), available at http://ssrn.com/abstract $=1120244$.

67 Fallon, supra note 35.

${ }^{68}$ Id. at 1317-18 (citation omitted).
} 
Fallon's distinction between the semantic content of the Constitution and the legal content of constitutional law put the following question of contribution on the table: How does the semantic content contribute to legal content?

\section{G. New Critics of the New Originalism}

This brings us almost up to the minute - up to late 2008 and early 2009, the period during which scholarly reaction to the Supreme Court's decision in Heller has begun to emerge. Coincidentally, Heller was decided shortly after several scholars had begun to criticize the most recent developments in originalist theory-we might call these scholars the "new critics" of the "New Originalism."

The first of the new critics is Stephen Griffin, the author of Rebooting Originalism, ${ }^{69}$ a powerful critique of the New Originalism. Griffin's critique has thoroughly absorbed the theoretical significance of the shift from original intentions to original public meaning, but it is not clear that he fully appreciates the importance of the Whittington/Barnett distinction between construction and interpretation. ${ }^{70}$ Although Griffin has a variety of important and well-argued criticisms of the new originalists, two features of his article are especially important for present purposes. First, Griffin's core argument against the New Originalism is normative: he argues that consistent and exclusive use of originalist methodology would represent a major change in interpretive practice and that originalists must therefore offer a normative justification for their theory. ${ }^{71}$ Second, Griffin's critique does not consider the possibility that original-meaning originalism might include a semantic thesis - a nonnormative claim about the meaning of the Constitution. ${ }^{72}$ A second new critic is Trevor Morrison, whose review of Barnett's book Restoring the Lost Constitution provides an illuminating perspective on Barnett's version of the New Originalism. ${ }^{73}$ Morrison clearly understands the distinction between original public meaning and original intentions, but his review does not even consider the possibility that Barnett's theory of constitutional meaning rests on a claim about the linguistic meaning of the Constitution.

\footnotetext{
69 Stephen M. Griffin, Rebooting Originalism, 2008 U. ILL. L. REV. 1185.

70 The distinction is never discussed in a theoretical way. The first mention appears on page 34 of his essay. Id. at 1217.

${ }^{71}$ Id. at $1196-1205$.

72 No variant of the root word "semantic" appears in Griffin's article. Although the term "meaning" and its variants appear numerous times, there is no indication that Griffin appreciates the possibility that originalism might be a semantic theory.

73 Trevor W. Morrison, Lamenting Lochner's Loss: Randy Barnett's Case for a Libertarian Constitution, 90 CORNELL L. REV. 839 (2005) (reviewing RANDY E. BARNETT, RESTORING THE LOST CONSTITUTION (2004)).
} 
A third new critic is Mitchell Berman, whose critique of originalism is tendentiously titled Originalism is Bunk. ${ }^{74}$ Berman's essay is deep and rich, raising some old objections to originalism, providing new foundations for others, and developing new positions. One of the crucial moves in his piece is his argument that the term "originalism" should be reserved for the strong claim that original meaning, whatever that might be, should trump other considerations in constitutional practice. He summarizes this claim as follows:

[O]n one dimension of potential variability-the dimension of strengthoriginalists are mostly united: They believe that those who should follow some aspect of a provision's original character must give that original aspect priority over all other considerations .... That is, when the original meaning (or intent, etc.) is satisfactorily discernible, the interpreter must follow it. This is the thesis that self-professed originalists maintain and that their critics (the nonoriginalists) deny. ${ }^{75}$

Berman's identification of "Originalism” (with a capital "O”) with what he calls "strong originalism" is surely mistaken. Justice Scalia's opinion in Heller did not dismiss precedent as irrelevant; instead, he argued that the only relevant precedent, United States $v$. Miller, ${ }^{76}$ was distinguishable. ${ }^{77}$ In 2006, the New Originalist theorist, Randy Barnett, wrote Scalia's Infidelity: A Critique of Faint-Hearted Originalism, which explicitly disagrees with Justice Antonin Scalia on the question of force, contending that Scalia allows departure from original meaning on the basis of three factors: (1) precedent, (2) justiciability, and (3) settled historical practice. ${ }^{78}$ In addition to Scalia, originalists of various stripes have taken the position that original meaning can be trumped by precedent for a variety of reasons and is subject to a variety of constraints, as evidenced by the work by Kurt Lash, Lee Strang, and this author. ${ }^{79}$ Confining "Originalism" (in its focal meaning) to the view that original meaning must trump all other considerations is misleading. Moreover, this move has the unfortunate effect of defining the to-

\footnotetext{
74 Mitchell N. Berman, Originalism is Bunk (Dec. 30, 2007), available at http://ssrn.com/abstract= 1078933.

${ }^{75}$ Id. (abstract).

76307 U.S. 174 (1939).

77 District of Columbia v. Heller, 128 U.S. 2783, 2814 (2008).

78 Randy E. Barnett, Scalia's Infidelity: A Critique of “Faint-Hearted” Originalism, 75 U. CIN. L. REV. 7, 13 (2006).

79 See Lash, Originalism, Popular Sovereignty, and Reverse Stare Decisis, supra note 43, at 1441 (stating that "popular sovereignty-based originalism" "does not require the complete abandonment of stare decisis" and "[a] theory of stare decisis that takes into account the majoritarian commitment of popular sovereignty may justify upholding an erroneous precedent”); Lawrence B. Solum, The Supreme Court in Bondage: Constitutional Stare Decisis, Legal Formalism, and the Future Of Unenumerated Rights, 9 U. PA. J. CONST. L. 155, 159 (2006) (arguing for originalist theory that gives trumping force to precedent); Lee J. Strang, An Originalist Theory of Precedent: Originalism, Nonoriginalist Precedent, and the Common Good, 36 N.M. L. REV. 419, 420 (2006) (offering originalist theory in which "limited respect is due some nonoriginalist constitutional precedent”).
} 
pography of argument in a way that eliminates plausible forms of originalism from the originalist camp, leaving only the most implausible and extreme views in contention. The equivalent move by a critic of nonoriginalism would be to define "Nonoriginalism" with a capital "N" as the view that "original meaning" in any form can never be considered in constitutional interpretation or construction. A more productive characterization of the debate might focus on three disagreements between originalists and nonoriginalists: (1) debates over the question whether the linguistic meaning of the Constitution should be viewed as fixed at the time each provision is framed and ratified, (2) arguments about the relative importance of the original meaning of the text versus other considerations, such as purpose, practice, precedent, and principles, and (3) differences over the extent to which constitutional construction is constrained by the linguistic meaning of the text.

\section{H. District of Columbia v. Heller}

Supreme Court decisions that squarely address the fundamental issues of constitutional theory are rare, but, as we have already seen, District of Columbia v. Heller ${ }^{80}$ is such a decision. The key passage in the majority opinion is unmistakably originalist: "In interpreting this text, we are guided by the principle that ' $[t]$ he Constitution was written to be understood by the voters; its words and phrases were used in their normal and ordinary as distinguished from technical meaning."”81 The implications of the majority's conclusion that the Second Amendment protects an individual right to possess and carry weapons were disputed by Justice Stevens and Justice Breyer in their dissenting opinions. Justice Stevens, in particular, offered a lengthy dissent, focusing in part on the purposes that animated the Second Amendment and raising a number of arguments relevant to the original intentions of the Framers. ${ }^{82}$

The majority opinion in Heller covers a good deal of territory, much of it contested by the dissents, but, for the purpose of completing this brief survey of the contemporary development of originalist theory, the important feature of Heller is methodological. The Court examined each of the operative words and phrases in the Second Amendment, examining the semantic content of "the people," "keep," "bear," and "arms." The Court concluded its examination as follows: "Putting all of these textual elements together, we find that they guarantee the individual right to possess and carry weapons in case of confrontation." ${ }^{83}$ In examining each of the operative words and phrases, the Court examined evidence of usage from the period the Second Amendment was proposed and ratified. For example:

\footnotetext{
80128 S. Ct. 2783.

81 Id. at 2788 (citations omitted).

82 See, e.g., id. at 2837 n.28 (Stevens, J., dissenting).

83 Id. at 2797 (majority opinion).
} 
Before addressing the verbs "keep" and "bear," we interpret their object: "Arms." The 18th-century meaning is no different from the meaning today. The 1773 edition of Samuel Johnson's dictionary defined "arms" as "weapons of offence, or armour of defence.” Timothy Cunningham's important 1771 legal dictionary defined "arms" as "any thing that a man wears for his defence, or takes into his hands, or useth in wrath to cast at or strike another." 84

Another example:

The phrase "keep arms" was not prevalent in the written documents of the founding period that we have found, but there are a few examples, all of which favor viewing the right to "keep Arms" as an individual right unconnected with militia service. William Blackstone, for example, wrote that Catholics convicted of not attending service in the Church of England suffered certain penalties, one of which was that they were not permitted to "keep arms in their houses." 85

Additionally: "At the time of the founding, as now, to 'bear' meant to 'carry. ${ }^{86}$

Bracketing the question as to whether Heller's analysis of the linguistic evidence was correct, the methodology of Justice Scalia's majority opinion was clear: the Court focused on the evidence of the original public meaning of the text. Given the inevitable differences between judicial practice and constitutional theory, it is hard to imagine finding a clearer example of original public meaning originalism in an actual judicial decision.

\section{LinguistiC MEANING AND LEGAL CONTENT}

Both contemporary originalist theory and the majority in Heller assume that the meaning of a constitutional provision is a function of its original public meaning as determined by usage at the time the provision was framed and ratified. What is the warrant for this assumption? We can answer this question in steps, beginning with a foundational question: What do we mean by "constitutional meaning”?

\section{A. The Meaning of Meaning}

We ask questions about constitutional meaning. What does the Second Amendment mean? What will Heller mean for state regulation of firearms? What was the meaning of the Framers' decision to preface "the right of the people to keep and bear Arms, shall not be infringed" with the phrase "A well regulated Militia, being necessary to the security of a free State"? These three questions reveal an ambiguity in the meaning of the word "meaning." When we refer to the meaning of a constitutional provision, we might refer to the linguistic meaning or semantic content. Call this first sense of meaning the semantic sense. But the term "meaning” can also be

84 Id. at 2791 (citations omitted).

85 Id. at 2792 (citations omitted).

86 Id. at 2793 (citation omitted). 
used to refer to implications, consequences, or applications. Call this second sense of meaning the applicative sense. We can also use the term "meaning" to refer to the purpose or function of a given constitutional provision. Call this third sense of meaning the teleological sense.

Constitutional practice can involve meaning in all three of these senses. We can inquire into the linguistic meaning of the Constitution: what is the semantic content of the words and phrases that comprise the constitutional text? We can ask about the applicative meaning of the Constitution: what are the implications of a given clause for a contemporary controversy? We can investigate the teleological meaning of the constitution: what purpose was some constitutional provision intended to serve?

If our aim is to explicate the theoretical foundations for the majority opinion in Heller, we shall need to be very clear about the meaning of "meaning." The theoretical approach adopted by the majority in Heller seeks to recover the linguistic meaning (or semantic content of the Constitution). Thus, the majority opinion searches for meaning in the semantic sense. The theoretical foundations of Justice Stevens's dissenting opinion are less transparent, but for the most part, his opinion addresses meaning in the teleological sense. The core of his position is that the purpose of the Second Amendment was not the protection of an individual right to possess and carry weapons for nonmilitary reasons.

Once we focus on the role of meaning in the semantic sense in the majority opinion, questions are raised about originalism as a constitutional theory. How can normative arguments establish linguistic meanings?

\section{B. Linguistic Facts and Normative Constitutional Theory}

The core argument of the majority opinion in Heller relies almost entirely on linguistic facts about patterns of language used at the time the Second Amendment was framed and ratified. As we have already seen, Justice Scalia's approach to the constitutional question is to inquire into the linguistic meaning of the operative clause of the Second Amendment: What does the phrase "the right to keep and bear arms" mean in the semantic sense of "meaning"? The majority answers this question: "Putting all of these textual elements together, we find that they guarantee the individual right to possess and carry weapons in case of confrontation." ${ }^{87}$ Thus, the first step of the majority's inquiry is about meaning in the semantic sense-it is not about the purpose or implications of the phrase. When offering warrants for this conclusion, Justice Scalia focused entirely on linguistic facts. Thus, in the passages cited above, he relied upon dictionaries for the meaning of "arms," ${ }^{88}$ and examined usage of the phrase "keep arms" ${ }^{89}$ and the word

${ }^{87}$ Id. at 2797.

${ }^{88}$ Id. at 2791.

89 Id. at 2792. 
"bear."90 Therefore, the warrants for the Court's conclusions about the meaning of "the right to keep and bear arms" were facts about patterns of language use. Such evidence consisted of direct evidence-actual examples of usage — and indirect evidence-dictionaries that summarized or reported observations about usage.

From a legal realist perspective, the focus on linguistic facts might seem surprising. Legal realism comprises a complex set of ideas with many different strands, but one important idea associated with realist and postrealist legal theory is what might be called the instrumentalist thesis. This thesis is roughly the proposition that the outputs of legal decisionmaking processes - paradigmatically, appellate adjudication—are, and should be, determined by extralegal considerations, notably policy or principle. ${ }^{11}$ For instrumentalists, the ultimate justifications for constitutional practice boil down to arguments of political morality. It would thus appear that Justice Scalia's opinion for the majority in Heller commits some kind of elementary category mistake: he seems to be attempting to derive an "ought" from an "is"- using linguistic facts as the premises for an argument that yields a normative conclusion in the form of a practical imperative or rule of constitutional law.

Both my characterization of the Heller opinions and of the instrumentalist thesis assume a fundamental distinction between linguistic facts on the one hand and moral, political, or legal norms on the other hand. Before we proceed any further, we can explicate the distinction between facts about linguistic practice, which we can call linguistic facts, and systematic judgments about the goodness or rightness of constitutional practice and institutions, which we can call normative constitutional theory.

What is a linguistic fact? The domain of semantics is the domain of meaning. A semantic theory is a theory of the meaning of utterances, usually in a natural language such as English. The semantic content of an utterance is its linguistic meaning. ${ }^{92}$ We can use the phrase linguistic fact to refer to facts about language usage that are relevant to meaning in the semantic sense. Along these lines, when we make assertions about what an utterance means, we are making factual assertions about the world. In the context of law, we are frequently interested in determining the semantic content of a legal text. Constitutions, statutes, judicial opinions, rules, and regulations all have semantic content, and both citizens and officials have practical reasons for ascertaining what that semantic content is. In particular, the Second Amendment of the Constitution of the United States is a text. Even if the United States Constitution were no longer in effect, we could still ask what the text of the Second Amendment means in the seman-

\footnotetext{
${ }^{90}$ Id. at 2793.

91 See Solum, supra note 79.

92 See Solum, supra note 66, at 2-3 \& n.5 and accompanying text (distinguishing three senses of meaning)
} 
tic sense. To answer that question, we would have to appeal to linguistic facts - to facts about usage.

What is normative constitutional theory? By using the term "normativity" and its root word "norm," I mean to refer to reasons for action in a somewhat restricted sense. ${ }^{93}$ In this restricted sense, normative theory includes moral philosophy, political theory, and normative legal theory; normative reasons include reasons drawn from consequentialist, deontological, and aretaic moral as well as political theory. In the context of law, normative theories address legal practice - in a stipulated sense in which the phrase "legal practice" refers to law-involving actions and choices, such as the activities of adjudicating legal disputes or complying with (or disobeying) the law. In the more particular context of the Constitution (or of constitutions generally), the activity of normative theorizing can be called "normative constitutional theory." We can understand normative constitutional theory as moral philosophy, political theory, and normative legal theory, all as applied to choices involving the Constitution, such as interpretation and construction of the Constitution by judges, other government officials, and ordinary citizens. ${ }^{94}$

What then is the relationship between linguistic facts and normative constitutional theory? The answer to that question is that the relationship is contingent. The linguistic meaning of Second Amendment might be important for constitutional practice-as the Heller majority thought it was. Or one might believe that other considerations are more important. For example, Justice Stevens's opinion could be understood as arguing that both precedent-United States $v$. Miller-and purpose-the goal of preserving state power over the militia-were more important than the meaning of the amendment in the semantic sense. Justice Breyer's opinion could be inter-

93 In the broadest sense, "normative" might refer to all reason-involving activity. Thus the broadest sense of "normative” would include reasons of prudence and reasons based on linguistic conventions. In that very broad sense, derivation of "semantic content" is normative, but in this Article I am not using "normative" in that broad sense. Some readers may be puzzled that I do not use either "moral" or "ethical" as the preferred term. The difficulty is that those words are sometimes taken as having a very restricted meaning in legal theory. For example, the term "moral" is sometimes read as referring only to deontological normative reasons; in this very restricted sense, consequentialist reasons are not "moral" reasons. I am not endorsing this very restricted sense of the term "moral." My point is simply that the different communities of scholars use these terms differently. The only solution is to define terms clearly or to invent a special technical vocabulary. Both options have their drawbacks, but I believe the best communicative strategy is to use the term "normative" and then clearly state that it is being used in a restrictive sense that focuses on the moral or ethical broadly construed to include consequentialist, deontological, and aretaic reasons as applied to both the personal and political dimensions of human conduct.

94 On the Constitution outside the courts, see, for example, Sotirios A. Barber \& James F. Fleming, The Canon and the Constitution Outside the Courts, 17 CONST. CommENT. 267 (2000); Lawrence G. Sager, Fair Measure: The Legal Status of Underenforced Constitutional Norms, 91 HARV. L. REV. 1212, 1213 (1978); Lawrence G. Sager, Justice in Plain Clothes: Reflections on the Thinness of Constitutional Law, 88 Nw. U. L. REV. 410, 419 (1993). 
preted as being based on the premise that policy concerns, as operationalized by a balancing test, should guide constitutional practice.

The key point is that the inquiry into meaning in the semantic sense is conceptually distinct from the normative inquiry about constitutional practice.

\section{Linguistic Facts and the Fixation of Meaning}

So far, we have distinguished linguistic facts from normative theory and disambiguated the three senses of meaning-semantic, applicative, and teleological. We now can attempt to uncover the assumptions that underlie the Court's reasoning. The following passage makes the key move: "In interpreting [the] text [of the Second Amendment], we are guided by the principle that ' $[\mathrm{t}] \mathrm{he}$ Constitution was written to be understood by the voters; its words and phrases were used in their normal and ordinary as distinguished from technical meaning.'"'95 This passage is suggestive, but it falls short of laying out a complete argument. How does the Court know that the "words and phrases were used in their normal and ordinary" meaning? Why should the "normal and ordinary meaning" guide constitutional interpretation? And why does the Court focus on evidence of "normal and ordinary meaning" in the eighteenth century as opposed to usage in the twenty-first century?

We can attempt to provide a theoretical foundation for Heller by exploring the last question posed: why the eighteenth century? The Court assumes that the meaning of "the right to keep and bear arms" is its original public meaning - the linguistic meaning at the time the Second Amendment was proposed and ratified. This assumption concerns meaning in the semantic sense because it relies on linguistic evidence, primarily usage or linguistic practice in the eighteenth century.

The best way to explain the Court's focus on the linguistic practice at the time that the Second Amendment was proposed and ratified is to attribute to the Court an additional unarticulated assumption: the majority in Heller assumes that the semantic meaning of the Second Amendment was fixed by linguistic facts at the time of origin. More generally, originalism assumes that the meaning of a given constitutional provision is fixed at the time the provision was framed and ratified. Let us call this assumption the fixation thesis.

The meanings of the individual words and phrases that comprise the Constitution may change over time, so why do originalists assume that constitutional meaning fixed at the time of origination? One common answer

95 District of Columbia v. Heller, 128 S. Ct. 2783, 2788 (2008). 
to this question focuses on the fact that the Constitution is written and that the function of a writing is to fix meaning through time. ${ }^{96}$

There is, however, a more fundamental warrant for the fixation thesis. That warrant can be seen most clearly if we focus on an example that does not involve the Constitution. Suppose, for example, that we are attempting to determine the semantic content of a letter written in the twelfth century that uses the term "deer." Over time, the meaning of the term "deer" has substantially changed. Today, "deer" refers to a ruminant mammal belonging to the family Cervidae; in addition, a number of broadly similar animals from related families within the order Artiodactyla are often also called deer. But in Middle English, the word "deer" meant a beast or animal of any kind. ${ }^{97}$ One can only understand an ordinary letter written between 1066 and the fifteenth century that employed the term "deer" by looking to the term's conventional semantic meaning at the time of writing; reading the letter and understanding the term "deer" to refer exclusively to a mammal belonging to the family Cervidae would be a type of factual error-a linguistic mistake. ${ }^{98}$ Although I have used an example involving a writing - a letter - this feature is not essential to fixation. The semantic content of a twelfth-century oral communication using the word "deer" would also be given by usage in Middle English. ${ }^{99}$

Similarly the Constitution of 1789 uses the phrase "domestic violence." 100 The contemporary semantic meaning of the phrase "domestic violence” is “'intimate partner abuse,' 'battering,' or 'wife-beating,"” and it is understood as "physical, sexual, psychological, and economic abuse that takes place in the context of an intimate relationship, including marriage."101 If that meaning was unknown in the late eighteenth century, it would be a linguistic mistake to interpret the domestic violence clause of Article IV of

\footnotetext{
96 See, e.g., RANDY BARNETT, RESTORING THE LOST CONSTITUTION, supra note 52, at 4; Randy E. Barnett, An Originalism for Nonoriginalists, supra note 48, at 611-29.

97 Sol Steinmetz, Semantic ANTiCs: How And Why Words Change MEANing 49-50 (2008).

98 Of course, the term "deer" in Middle English included what we call deer in contemporary usage, and it might be clear in context that a particular letter used the Middle English term to refer to a modern deer. Such usages were, in fact, a part of the causal chain that resulted in the contemporary usage. The mistake would be to assume that the Middle English term was limited to the modern usage. The mistake would result in a gross misunderstanding where the Middle English term was used to refer to what we call a "cow" or a "pig."

99 Since there were no sound recordings in the twelfth century, we could only know of such an utterance through a contemporaneous written report.

${ }^{100}$ U.S. CONST. art. IV, § 4 ("The United States shall guarantee to every state in this Union a Republican Form of Government, and shall protect each of them against Invasion; and on Application of the Legislature, or of the Executive (when the Legislature cannot be convened) against domestic Violence.”); see 1 LAURENCE H. TRIBE, AmERICAN CONSTITUTIONAL LAW § 1-14, at $52-53$ (3d ed. 2000).

${ }^{101}$ Glossary, Human Rights Watch, http://www.hrw.org/reports/2003/nepal0903/3.htm (last visited March 29, 2008); see also Times Topics, Domestic Violence, N.Y. TIMEs, http://topics.nytimes. com/top/reference/timestopics/subjects/d/domestic_violence/index.html?scp=1\&sq=“domestic\%20viole nce"\&st=cse (last visited Feb. 24, 2009) (gathering news articles that relate to "domestic violence" which refer to acts of violence within families and groups that live in communal settings).
} 
the Constitution of 1789 as referring to spouse or child abuse. The anachronistic reading of "domestic violence" would be mistaken because the semantic content is fixed at the time of "constitutional utterance." Indeed, the phrase is understood as referring to its meaning at the time of origin, which encompasses the period roughly contemporaneous with the Framing and ratification —or formal legal approval — of the particular clause or amendment. ${ }^{102}$

The fixation thesis is within what we can call the core content of originalism, and the claim advanced by the fixation thesis should be regarded as neutral between almost all the members of the originalist family. Original intentions originalists believe that the original meaning of the Constitution is a function of the intentions of the Framers. If this view of constitutional meaning were correct, then the semantic content of a constitutional provision would be fixed at the time of drafting; the fixation would be established by the mental states, or intentions, of the Framers, and those states would be fixed at the time of constitutional utterance. Similarly, original public meaning originalists believe that the original meaning of the Constitution is a function of the original public meaning - or "conventional semantic meaning"- of a given constitutional provision at the time the provision was framed and ratified. Once again, meaning is fixed by the general pattern of usage at the time of constitutional utterance: It is the conventional pattern of usage and not the intentions of particular Framers or ratifiers that fixes the semantic content of the constitutional text.

The Court in Heller did not explicitly articulate its use of the fixation thesis. The majority does, however, refer to eighteenth-century usage and meaning at the time of the adoption of the Second Amendment in numerous passages: the opinion refers to "founding era," 103 "18th century meaning," 104 "the founding period," 105 "the time of the founding," 106 "in the 18th century," 107 "in the 18th century or the first two decades of the 19th," ${ }^{108}$ and "historical usage." 109 Moreover, the Court does not cite evidence of usage from other periods, such as early twenty-first-century usage or fifteenthcentury usage. This strongly suggests that the majority opinion is premised on the notion that the linguistic meaning of the Second Amendment was

\footnotetext{
102 I owe this example to Jack Balkin. See Lawrence B. Solum, Blogging from APSA: The New Originalism, Legal Theory Blog, Sept. 3, 2007, http://lsolum.typepad.com/legaltheory/2007/09/ blogging-from-a.html (live blogging at the meeting of the American Political Science Association and describing Balkin's presentation).

103 District of Columbia v. Heller, 128 S. Ct. 2783, 2790 n.6 (2008).

104 Id. at 2791.

105 Id. at 2792, 2797.

106 Id. at 2793.

$107 \mathrm{Id}$.

$108 \mathrm{Id}$.

109 Id. at 2797 n.14.
} 
fixed by linguistic facts-patterns of usage-at the time of utterance, not before and not after.

\section{Clause Meaning or Framers' Meaning}

We have already observed the evolution of originalist theory from the 1970s through the present. The tie that binds these theories together is the fixation thesis. Some original intentions originalists believe that the meaning of the Constitution was fixed by the intentions of the Framers-those who actually drafted the document. Other original intentions originalists believe that the intentions of the ratifiers fixed constitutional meaning. Alternatively, New Originalists (or original public meaning originalists) believe that patterns of usage by the public at the time of adoption fixed the meaning of the Constitution. The next step in our analysis of Heller is to provide foundations for the Court's adoption of original public meaning as opposed to some other originalist theory.

At the level of explanation, as opposed to justification, Heller's embrace of original public meaning is easy to understand. Justice Scalia, the author of the majority opinion in Heller, was a key figure in the development of original public meaning originalism. ${ }^{110}$ Original intentions originalism has been subject to a withering critique, and the turn to public meaning was an answer that helped avoid the objections raised by Brest and others. ${ }^{111}$

But explanation is not justification. The question is whether we can provide adequate theoretical foundations for Heller's turn to original public meaning. Is the linguistic meaning of the Second Amendment really the "normal and ordinary" meaning of its words and phrases? This is not a legal question; it is instead a question of linguistics or the philosophy of language. Of course, the linguistic meaning of a text may (or may not) constrain the legal effects of the text: meaning in the semantic sense can influence meaning in the implicative sense. But at this stage of the analysis, we are focused on the linguistic meaning of the Second Amendment.

We can begin our investigation by examining Paul Grice's distinction between "speaker's meaning" and "sentence meaning."112 (The phrase "expression meaning" is sometimes used as an equivalent for "sentence meaning"; I will use "sentence meaning" for the remainder of this Article.) ${ }^{113}$

\footnotetext{
110 See supra Part I.E.

111 See supra Part I.B.

112 See PAUL GRICE, StUdies IN THE WAY OF WORDs 3-143 (1989); see also Jeffrey Goldsworthy, Legislative Intentions, Legislative Supremacy, and Legal Positivism, 42 SAN DIEGO L. REV. 493, 510 n.57 (2005); B. Jessie Hill, Putting Religious Symbolism in Context: A Linguistic Critique of the Endorsement Test, 104 Mich. L. Rev. 491, 506 (2005); John F. Manning, What Divides Textualists from Purposivists?, 106 COLUM. L. REV. 70, 72 n.7 (2006).

113 In his analysis of Heller, Saul Cornell has asserted that the Gricean account offered in Solum, Semantic Originalism, supra note 66, has been critiqued by Stephen Griffin. See Cornell, supra note 6, at 626 n.5. This is an error. In support of his assertion, Cornell cites Stephen M. Griffin, Rebooting Originalism, 2008 U. ILL. L. REV. 1185 (2008). In that article, Griffin did cite a twenty-year-old article,
} 
Grice's idea of speaker's meaning is actually quite familiar. We look for speaker's meaning all the time in ordinary conversations, for example, when we ask, "What did she mean by that?" In the context of legal texts, we ask similar questions: "What did the legislature mean by the provision?" "What did the judge mean by that sentence in the opinion?" "What did the Framers mean by that clause in the Constitution?" Grice contended that speaker's meaning can be analyzed in terms of a speaker's (or author's) intentions. His point is illustrated by the following thought experiment:

[I]magine that you have stopped at night at an intersection. The driver of another car flashes her lights at you, and you make the inference the reason for her doing this is that she wants to cause you to believe that your lights are not on. And based on this inference, you now do, in fact, realize that your lights are not on. ${ }^{114}$

In this example, the meaning of the flashing lights is the product of the following complex intention-as explicated by Richard Grandy and Richard Warner:

The driver flashes her lights intending

1) that you believe that your lights are not on;

2) that you recognize her intention ...

3) that this recognition be part of your reason for believing that your lights are not on. ${ }^{115}$

In the case of imperatives, for example, the intention is that the audience performs a certain act on the basis of its recognition of the speaker's intention that the audience perform the act. A viable application of "speaker's meaning" requires that speakers and audiences have "common knowledge" 116 or "reciprocal knowledge" in a technical sense: the speaker must

Lawrence B. Solum, Originalism as Transformative Politics, 63 TuL. L. REV. 1599 (1989), with approval. Id. at 1192. Griffin's article does not use the words "semantic" or "linguistic" or mention the work of Paul Grice. Griffin's article does not mention or cite Semantic Originalism. No passage in the article that Cornell cites can reasonable be construed as "a thoughtful critique of Solum's variant of originalism.” Cornell, supra note 6, at 626 n. 5. Griffin did comment on Semantic Originalism in a post on Balkinization. See Stephen Griffin, Solum on Semantic Originalism, Balkinization, Apr. 27, 2008, http://balkin.blogspot.com/2008/04/solum-on-semantic-originalism.html. Griffin's post is discussed at length in Lawrence B. Solum, A Reader's Guide to Semantic Originalism and a Reply to Professor Griffin (Illinois Pub. Law and Legal Theory Research Papers Series No. 08-12, 2008), available at http://papers.ssrn.com/sol3/papers.cfm?abstract_id=1130665.

114 Richard E. Grandy \& Richard Warner, Paul Grice, STANFORd EnCyClopedia OF Philosophy, (Edward N. Zalta ed., rev. ed. 2008), http://plato.stanford.edu/entries/grice/.

${ }^{115}$ Id.

116 On common knowledge, see Peter Vanderschraaf \& Giacomo Sillari, Common Knowledge, STANFORD ENCYCLOPEDIA OF PHILOSOPHY, supra note 114, http://plato.stanford.edu/entries/commonknowledge (distinguishing "mutual knowledge," which is shared without knowledge of the fact of sharing from "common knowledge," which requires knowledge of the fact that content is shared). See also Michael Suk-Young Chwe, Rational Ritual: Culture, Coordination, and Common KNOWLEDGE 3, 8-10 (2001). This idea of common knowledge was introduced (so far as I know) by David Lewis. See David K. Lewis, Convention: A Philosophical Study 52-60 (1969). 
know what the audience knows about the speaker's intentions and vice versa.

We can tentatively formulate the notion of speaker's meaning as follows:

Speaker's meaning: The speaker's meaning (or utterer's meaning) of an utterance is the understanding that the speaker intended to produce in the audience on the basis of the audience's recognition of the speaker's intention.

Grice formulated his notion in terms of speakers (or utterers) and audiences, implicitly assuming that the context of oral communication between a speaker and an audience is contiguous in space and time. Let us assume that this notion could be generalized to include written communication, so long as the author of the text and the reader of the text could satisfy the conditions for common knowledge of the author's beliefs regarding reader recognition of the author's intentions. Thus, the "author's meaning" of a text would be the illocutionary uptake that the author intended to produce in the reader on the basis of the reader's recognition of the author's intention.

What about sentence meaning? In its simplest (and perhaps simplified) form, the idea is that words and expressions have standard meanings - the meanings that are conventional, given relevant linguistic practices. As Hurd puts it: "[i]n other words, the sentence meaning of a particular utterance can be understood not by reference to the illocutionary intentions of the speaker, but rather by reference to the illocutionary intentions that speakers in general have when employing such an utterance.”117 Hurd goes on to criticize this solution, but I want to put this sort of controversy to the side at this point. For now, let us tentatively use the following formulation:

Sentence meaning: the sentence meaning (or "expression meaning”) of an utterance is the conventional semantic meaning of the words and phrases that constitute the utterance.

The phrase "sentence meaning" does not contain the same implicit reference to oral communication under conditions of proximity. Thus, texts and speeches can have "sentence meaning," irrespective of whether the utterance is read or heard in spatial and temporal proximity to the occasion of writing or saying, and without satisfaction of the common knowledge conditions required for successful communication of "speaker's meaning."

How does Grice's distinction apply to legal texts in general and the Second Amendment in particular? We can specify a contextually bounded version of "speaker's meaning" in the context of constitutional communication: the speaker's meaning of a constitutional provision is what we can

${ }^{117}$ Heidi M. Hurd, Sovereignty in Silence, 99 YALE L.J. 945, 964 (1990). 
stipulate shall be called its framers' meaning. ${ }^{118}$ The framers' meaning of the United States Constitution would be the content that its authors intended the audience to grasp based on the audience's recognition of the Framers' intentions. In this case, the audience of the Constitution would be a variety of groups, including the members of the various ratifying conventions, officials-including judges, Presidents, officers of executive departments, members of Congress, and various equivalent officers of state and local governments - and citizens. The "intended audience" for the United States Constitution was extended over time. Most immediately, the text was directed at state legislatures and participants in the ratification process. In the next period, the text was directed at those who organized the first Congress, conducted the first election for members of the Electoral College, and so forth. But the primary audience for the Constitution was the collection of citizens and officials who would be governed by its provisions for the indefinite period during which provisions of the Constitution of 1789 would remain in effect - an audience that continues today and seems likely to continue for many decades or centuries to come.

Is framers' meaning possible? ${ }^{119}$ Another way of framing the question is to ask whether constitutional communication is possible if the content to be conveyed is framers' meaning. ${ }^{120}$ And yet another formulation of the issue might focus on the question of whether the conditions that attend the Framing and ratification of a constitution by multimember groups for distant future audiences can satisfy the common knowledge condition for the successful communication of speaker's meaning.

118 The phrase "framers' meaning” (no capitalization of the word "framers") shall be used to designate the theoretical concept introduced in the text that accompanies this footnote: the framers' meaning of a legal text is the meaning that the authors of the text would intend readers to recognize based on the readers' recognition of the framers' intent. This notion of framers' meaning is general and could be applied to any constitution, statute, or rule. References to the "Framers" of the United States Constitution will be capitalized. This term "framers" in the phrase "framers' meaning" is used generically to refer to the authors of a constitution (in the generic sense), whoever they may be. Given this stipulated definition, "framer's meaning" might be used to refer to the meaning intended by either the Framers or the ratifiers of the United States Constitution-depending on which group is considered to be the authors in a particular version of original intentions originalism.

119 The sense of "possibility" needs to be further specified. My claim is that "framers' meaning" is impossible in practically accessible possible worlds - worlds that are historically and nomologically accessible. See Lawrence B. Solum, Constitutional Possibilities, 83 IND. L.J. 307, 318-19 (2008).

120 The idea of constitutional communication is undertheorized in this Article. I am grateful to Guyora Binder for this point. As a preliminary correction for this deficiency, I offer the following remarks. Constitutional communication is the process by which semantic content is communicated by a complex group of constitutional authors-roughly the Framers and ratifiers-to a complex group of constitutional readers, which includes the ratifiers (who are both readers and authors), the initial group of implementing officials, citizens, future courts, future officials, and so forth. The "possible conditions for constitutional communication" refers to those facts about the circumstances of constitutional utterance that enable constitutional communication. The argument of this Article is that one of the success conditions is the existence of "public meaning" or "conventional semantic meaning." Similarly, this Article argues that "framers' meaning” (or "speaker's meaning”) does not satisfy the success conditions for constitutional communication because the common knowledge condition is not satisfied. 
The criteria for the possibility of successful communication of framers' meaning are established by Grice's theory of speaker's meaning. For the Constitution to have framers' meaning, it must have been possible for the Framers to have intended that citizens and officials, contemporaneously and over an indefinite future span, grasp the illocutionary force of the Constitution on the basis of their recognition of the Framers' intentions. But as many readers will have surmised, the satisfaction of these conditions is problematic, given the conditions of constitutional utterance. At a very high level of abstraction, this point was made by Michael Moore more than a quarter-century ago:

As utterances, statutes lack many of the non-linguistic, contextual features which constitute the foundation for a pragmatics analysis. Statutes are institutionalized utterances. Consequently, the richness of time and circumstance which the pragmatic approach embraces to interpret the intent of an ambiguous expression is eliminated by this institutionalized nature of statutes. ${ }^{121}$

Moore's point about context is refracted in a variety of criticisms of original intentions originalism. If restated, these arguments represent the reasons why framers' meaning fails as a theory of constitutional semantics. The arguments are familiar to constitutional theorists via the criticisms of original intentions originalism that Brest and others have articulated. The conditions for successful communication of framers' meaning were not met due to the historical circumstances in which the United States Constitution was framed and ratified. There were multiple Framers with various intentions, and the content of their intentions was not accessible to those who needed to comprehend the Constitution - the ratifiers and those whom the Constitution would bind over time. Successful communication of framers' meaning (to the extent that it deviates from clause meaning) is not possible, and as a consequence, the linguistic meaning of the Constitution cannot correctly be understood on the model of "speaker's meaning." The fundamental problem is not that we cannot know what framers' meaning is; rather, the problem is that framers' meaning simply does not exist. ${ }^{122}$

What about sentence or expression meaning? In the context of the Constitution, the equivalent idea is clause meaning - the meaning of the constitutional text is a function of the conventional semantic meaning of the words and phrases combined by the rules of syntax into clauses, which

\footnotetext{
121 Michael S. Moore, The Semantics of Judging, 54 S. CAL. L. REV. 151, 186-87 (1981).

122 The significance of this argument is easily misunderstood. Given the success conditions for the creation of framers' meaning, it is unlikely that framers' meaning ever comes into existence. Given the conditions of constitutional communication that almost always (or just always) obtain, there is no framers' meaning for most or all of the provisions of the constitutional text. The argument is not that the meaning exists, but we don't know what it is. Put somewhat differently, the critique of framers' meaning is metaphysical and not epistemological. The reason that the metaphysical nature of this point is easy to misunderstand is subtle but important. Because the existence conditions for framers' meaning include the existence of common knowledge of intentions, it is easy to confuse the metaphysics with the epistemology.
} 
function as operative units of meaning in the constitutional context. As Blackstone wrote, "[w]ords are generally to be understood in their usual and most known signification." ${ }^{123}$ Original meaning originalism emphasizes the meaning that the Constitution or its amendments would have had to the relevant audience at the time of adoption. Thus, the pertinent question in the recognition or discovery ${ }^{124}$ of clause meaning is: How would the Constitution of 1789 have been understood by a competent speaker of American English at the time it was adopted? This question points us to ordinary and conventional meanings of the words and phrases of the Constitution. Rather than assigning these words and phrases special or idiosyncratic meanings based on the secret and divergent intentions of multiple authors, an ordinary member of the public would have been required to look to common usage and public meanings.

As twenty-first century citizens and officials, we are not ordinary members of the public of 1789. Contemporary American English is not identical to late eighteenth-century American English. Yet in many cases, contemporary meaning will be identical to the meaning at the time of utterance. In theory and practice, however, there will be cases of divergence. For us to determine whether there is divergence with respect to a particular clause, we would be required to consult evidence as to late eighteenthcentury usage. Such evidence might include newspapers, political pamphlets, and a variety of other general sources for evidence about the meaning of particular phrases. We might also examine evidence that is directly connected to the drafting and ratification of the Constitution. For example, the debates at the Constitutional Convention in Philadelphia may shed light on the question of how the Constitution produced by the Convention would have been understood by those who did not participate in the secret deliberations of the drafters.

While the success conditions for framers' meaning are not satisfied, the relevant success conditions for clause meaning are met for the United States Constitution in general and the Second Amendment in particular, so long as the text of the Constitution satisfies two additional requirements. First, for a given constitutional provision to have clause meaning, it must employ words and phrases that had conventional semantic meanings at the time of utterance. Second, the clauses must be constructed in conformity with prevailing syntax so that the clauses make grammatical sense. In the case of the Second Amendment, these criteria would be satisfied if the words and phrases, such as "keep and bear arms," had conventional semantic meanings at the time the Second Amendment was proposed and ratified.

\footnotetext{
1231 Blackstone’s Commentaries 59-61 (St. George Tucker ed., Philadelphia, Birch \& Small 1803).

124 The phrase "recognition or discovery" is chosen with care and used in preference to "determination" or "attribution" in order to convey the factual nature of the inquiry.
} 
In sum, Heller assumes that the linguistic meaning of the constitutional text is a function of the "normal and ordinary as distinguished from technical meaning" of the words and phrases as determined by the rules of syntax and grammar. The theoretical foundations for that assumption can be reconstructed via Paul Grice's distinction between speaker's meaning and sentence meaning. That reconstruction yields the notion of clause meaning: the clause meaning thesis is the claim that the linguistic meaning (or semantic content) of the Constitution is its clause meaning, which is (i) fixed at the time each constitutional provision was framed and ratified, and (ii) determined by the relevant linguistic facts that establish conventional semantic meaning.

Our next topic is the relationship between the linguistic meaning (or semantic content) of the constitutional text and the legal content of the constitutional doctrine. But before we go there, one important qualification should be placed on the table. In this Article, only two theories of linguistic meaning are addressed: the content of those theories roughly correspond to original intentions originalism (framers' meaning) and original public meaning originalism (clause meaning). There are, however, a variety of other possible (if not plausible) theories of constitutional meaning. The linguistic meaning of the constitutional text might be provided by its legal meaning to judges, its contemporary meaning to ordinary citizens, the expectations of the Framers about its future applications, and so forth. In this Article, these important questions are set to the side, but they are considered in depth in other work. ${ }^{125}$

\section{E. Semantic Content and Legal Content}

Let us assume, for purposes of argument, that the fixation thesis and the clause meaning thesis are true. These assumptions would not be sufficient to establish the conclusion that the linguistic meaning of the Second Amendment is the law. It is at least conceivable that the meaning of the constitutional text and the content of the rules of constitutional law are not identical. The text might be viewed as merely advisory or as the starting point for a living constitution that officials-judges, executives, and legislators - could adapt to changing circumstances.

This possibility (that constitutional doctrine might be unconstrained by the text) reveals yet another unstated assumption in the reasoning of Heller. The majority assumes that in the absence of controlling precedent, the linguistic meaning of constitutional text must provide some of the content of the corresponding doctrines of constitutional law. We can use the term "contribution" to denote the relationship between semantic content-the linguistic meaning of the text-and legal content-the doctrines or rules of constitutional law. Heller implicitly assumes that the linguistic meaning of

125 See Solum, supra note 66, at 96-120. 
Second Amendment contributes to legal content of constitutional law. ${ }^{126}$ We might call this assumption the contribution thesis.

What warrants the assumption in Heller that the linguistic meaning of the Constitution constrains the content of constitutional doctrine? One can imagine a variety of arguments for this assumption. One argument would be legal: that there is a rule of law requiring officials, including judges, to conform the content of constitutional law to the semantic content of the constitutional text. There is considerable evidence that the conventions of legal practice in the United States include such a rule. Although the Supreme Court sometimes openly engages in the creation of supplementary rules of constitutional law, it is difficult to find clear examples of the Court announcing a constitutional doctrine that is inconsistent with the constitutional text. In those rare cases where a constitutional amendment purports to overrule a Supreme Court decision-for example, the Eleventh Amendment overruled Chisholm v. Georgia ${ }^{127}$ - the Court has uniformly acquiesced. No decision of the Supreme Court of which I am aware claims that the Court has the authority to override the text of the Constitution.

In sum, Heller's reasoning is incomplete from the perspective of constitutional theory or jurisprudence. The reconstruction of a complete justification for the result in Heller would need to include support along the lines of the following three additional premises: (1) a premise about fixation-the linguistic meaning of the constitutional text was fixed by linguistic facts at the time the text was framed and ratified; (2) a premise about clause meaning - the linguistic meaning of the constitutional text is given by the conventional semantic meaning of the words and phrases; and (3) a premise about contribution - the content of constitutional law is constrained by the linguistic meaning of the constitutional text.

This completes our investigation of Justice Scalia's majority opinion in Heller. We have reached the conclusion that the theory of constitutional interpretation in Heller is originalist - and more particularly, that the majority has adopted what is sometimes called original public meaning originalism or the New Originalism. The most plausible reconstruction of the theory that would need to be offered to justify this approach distinguishes between questions about meaning in the semantic sense and questions of normative constitutional theory. Most of the argumentation in the Heller majority goes to a question of linguistic fact: what was the conventional semantic meaning of the words and phrases that make up the Second Amendment? That approach is warranted by the theory of meaning-as exemplified by

\footnotetext{
126 Notice that this is not the same as the assumption that the linguistic meaning of text fully determines constitutional doctrine. As we have already noted, New Originalists distinguish between constitutional interpretation and constitutional construction: interpretation is about meaning in the semantic sense, but constitutional construction involves the supplementation of that meaning, characteristically in cases where the meaning is vague. See supra Part II.E.

1272 U.S. (2 Dall.) 419 (1793).
} 
the accounts of framers' meaning and clause meaning. A complete reconstruction of the argument for the result in Heller would also need to address the legal significance of the linguistic meaning of the constitutional text. One strategy for providing such an argument would focus on the conventions of legal practice, which strongly support the notion that the semantic context of the Constitution is law that cannot be overridden by the decisions of the Supreme Court.

\section{TELEOLOGICAL MEANING AND JUSTICE STEVENS's DISSENT}

Justice Stevens contested Justice Scalia's claim that the original meaning of the Second Amendment includes an individual right to possess and carry weapons outside the context of service in a state militia. Much of the disagreement between the five Justices in the majority and the four Justices who dissented may be empirical: they may simply disagree about linguistic facts. That disagreement is important, but it is not our topic on this occasion. Instead, the focus will be on the theoretical source of the disagreement: To what extent did Justice Scalia and Justice Stevens disagree about constitutional theory?

\section{A. The Two Clauses of the Second Amendment}

The Second Amendment reads in full: "A well regulated Militia, being necessary to the security of a free State, the right of the people to keep and bear Arms, shall not be infringed." ${ }^{28}$ Much of the disagreement among the justices in Heller concerned the relationship between the two clauses. This disagreement points to a larger question about the relationship between semantic meaning and teleological meaning in constitutional practice.

Justice Scalia's opinion for the Court in Heller divides the text into two parts: the prefatory clause and the operative clause. ${ }^{129}$ The majority's view is that the first part of the amendment does not alter or qualify the semantic content of the second part:

The former does not limit the latter grammatically, but rather announces a purpose. The Amendment could be rephrased, "Because a well regulated Militia is necessary to the security of a free State, the right of the people to keep and bear Arms shall not be infringed." 130

This does not imply that the prefatory clause is meaningless, but its role is limited to the resolution of ambiguity:

\footnotetext{
128 U.S. CONST. amend. II.

129 District of Columbia v. Heller, 128 S. Ct. 2783, 2789 (2008).

130 Id. (quoting J. TifFANY, A TREATISE ON GOVERNMENT AND CONSTITUTIONAL LAW $\S 585$, at 394 (1867)).
} 
Logic demands that there be a link between the stated purpose and the command. The Second Amendment would be nonsensical if it read, "A well regulated Militia, being necessary to the security of a free State, the right of the people to petition for redress of grievances shall not be infringed.” That requirement of logical connection may cause a prefatory clause to resolve an ambiguity in the operative clause ("The separation of church and state being an important objective, the teachings of canons shall have no place in our jurisprudence." The preface makes clear that the operative clause refers not to canons of interpretation but to clergymen.) But apart from that clarifying function, a prefatory clause does not limit or expand the scope of the operative clause. $^{131}$

In his dissenting opinion, Justice Stevens sharply criticized this understanding of the significance of the prefatory clause and articulated an alternative interpretation:

The preamble thus both sets forth the object of the Amendment and informs the meaning of the remainder of its text. Such text should not be treated as mere surplusage, for "[i]t cannot be presumed that any clause in the constitution is intended to be without effect."

Stevens then questioned the majority's decision to limit the effect of the prefatory clause to the resolution of ambiguity:

That is not how this Court ordinarily reads such texts, and it is not how the preamble would have been viewed at the time the Amendment was adopted. While the Court makes the novel suggestion that it need only find some "logical connection" between the preamble and the operative provision, it does acknowledge that a prefatory clause may resolve an ambiguity in the text. Without identifying any language in the text that even mentions civilian uses of firearms, the Court proceeds to "find" its preferred reading in what is at best an ambiguous text, and then concludes that its reading is not foreclosed by the preamble. Perhaps the Court's approach to the text is acceptable advocacy, but it is surely an unusual approach for judges to follow. ${ }^{133}$

Justice Stevens suggested that the meaning of the amendment is something like the following gloss: The right of the people to use and possess arms in conjunction with service in a well-regulated militia shall not be infringed. ${ }^{134}$

From the perspective of originalist theory, the interesting question about Justice Stevens's opinion concerns the implicit and unarticulated theory of "meaning" upon which he based his argument. It is clear that the text of the Second Amendment cannot fairly be read as directly expressing semantic content equivalent to Justice Stevens's gloss. The prefatory clause

\footnotetext{
131 Heller, 128 S. Ct. at 2789.

132 Id. at 2826 (Stevens, J., dissenting) (citation omitted).

133 Id. (footnote and citation omitted).

134 This is suggested by the following passage later in Justice Stevens's dissenting opinion: "When each word in the text is given full effect, the Amendment is most naturally read to secure to the people a right to use and possess arms in conjunction with service in a well-regulated militia.” Id. at 2831.
} 
contains an assertion about the relationship between the militia and the defense of a free state; it does not modify "the right to keep and bear arms" explicitly so as to directly express the implicit limitation that Justice Stevens believes is present in the operative clause. It is possible, of course, that Justice Stevens simply made a mistake about English grammar, but this seems unlikely. The more charitable interpretation is that his dissenting opinion rests on theoretical assumptions that are inconsistent with the clause meaning thesis or the contribution thesis.

\section{B. Justice Stevens's Dissent and Teleological Meaning}

This disagreement between Justices Scalia and Stevens about the relationship between the prefatory and operative clauses points to a larger disagreement. While Justice Scalia inquired into the semantic content of the operative clause, Justice Stevens focused on the purpose or teleological meaning of the Second Amendment. In a rough way, this disagreement corresponds to the difference between original intentions originalism and original meaning originalism. There is extensive evidence of an emphasis on intentions in Stevens's dissent, including the following passages:

- "The opinion the Court announces today fails to identify any new evidence supporting the view that the Amendment was intended to limit the power of Congress to regulate civilian uses of weapons."

- " [T] $]$ he Second Amendment's omission of any statement of purpose related to the right to use firearms for hunting or personal self-defense, is especially striking ....,136

- " $[T]$ he ultimate purpose of the Amendment was to protect the States' share of the divided sovereignty created by the Constitution." ${ }^{37}$

- "The history of the adoption of the Amendment thus describes an overriding concern about the potential threat to state sovereignty that a federal standing army would pose, and a desire to protect the States' militias as the means by which to guard against that danger." ${ }^{\prime 38}$

- "The evidence plainly refutes the claim that the Amendment was motivated by the Framers' fears that Congress might act to regulate any civilian uses of weapons." 139

A similar concern with purpose is mentioned (but does not play a prominent role) in Justice Breyer's separate dissent:

135 Id. at 2823.
136 Id. at 2825.
137 Id. at 2827.
${ }^{138}$ Id. at 2836.
139 Id. 
[T]he Second Amendment protects militia-related, not self-defense-related, interests. These two interests are sometimes intertwined. To assure 18thcentury citizens that they could keep arms for militia purposes would necessarily have allowed them to keep arms that they could have used for self-defense as well. But self-defense alone, detached from any militia-related objective, is not the Amendment's concern. ${ }^{140}$

In both dissents, the clear implication is that if the purpose of the Second Amendment is militia-related, so it follows that the Amendment does not create a legal rule that protects an individual right to possess and carry firearms outside the context of service in a state militia. The majority approach is different - the primary question is the linguistic meaning of the phrase "the right to keep and bear arms." For Justice Scalia, if the conventional semantic meaning of this phrase would encompass an individual right outside of militia service, then the purpose for which it was adopted does not limit either that linguistic meaning or the resultant rule of constitutional law.

What is the nature of this disagreement? There are at least two possibilities. One possibility is that the Justices are disagreeing about linguistic meaning. It seems clear that the majority opinion in Heller makes claims about the linguistic meaning of the Second Amendment based on an underlying assumption that meaning in the semantic sense is determined by the conventional semantic meaning of the words and phrases at the time the Amendment was adopted. Do Justices Stevens and Breyer disagree? The answer to that question is not easily discerned from their opinions. Neither of the dissenting opinions expresses a general theory of constitutional meaning. And neither of them explicitly embraces original intentions originalism. Neither Justice Stevens nor Justice Breyer was characterized as an originalist prior to authoring their dissenting opinions in Heller. It is an open question whether Stevens or Breyer would deny the clause meaning thesis because they affirm its rival-which we might call the framers' meaning thesis - but the evidence for an affirmative answer to that question is scanty at best.

Is there another explanation for the theoretical basis of the disagreement between the majority and the dissenters?

\section{Instrumentalism and Formalism in Constitutional Theory}

There is a second possible interpretation of the nature of the disagreement among the Justices in Heller. The alternative possibility is that the dissenting opinions disagree with the majority about the legal significance of the purposes that motivated the adoption of the Second Amendment. This possibility relates to a general jurisprudential debate that can be characterized as a disagreement between formalists and instrumentalists (or tex-

${ }^{140}$ Id. at 2847 (Breyer, J., dissenting). 
tualists and purposivists). On the one hand, some theorists and judges believe that legal content is strongly constrained by the semantic content of legal texts: the meaning of a statute or constitutional provision must be consistent with linguistic meaning of its words and phrases. On the other hand, there is another group of theorists who believe that the primary determinant of the content of legal rules should be the underlying purpose or function of the legal provision, even if the result required by the purpose departs from the linguistic meaning of the text.

It is possible that the theoretical foundation of the disagreement between the majority and dissenters in Heller would place Justice Scalia in the formalist camp and assign Justices Stevens and Breyer to instrumentalist contingent.

With respect to Justice Breyer, an instrumentalist reading of his opinion in Heller is not wholly implausible. Justice Breyer's dissent in Heller does not display any commitment to formalist or textualist approaches to constitutional interpretation. Indeed, the word "text" appears only once, and that appearance emphasizes the supporting role of the text in discerning the purpose of the Second Amendment. ${ }^{141}$ Justice Stevens's opinion however, includes numerous passages indicating that his reading of the Amendment is supported or required by the text. ${ }^{142}$

Heller produced a remarkable set of opinions, with unusually explicit focus on questions of original meaning. Justice Stevens opinion is wideranging and argumentative, advancing a hodge-podge of critical arguments. Unlike Justice Scalia's opinion, which clearly articulates a theory of constitutional interpretation, Justice Stevens's concurrence is theoretically opaque-its premises require extensive reconstruction. Nonetheless, one conclusion seems clear: Justice Stevens believes that the purposes of the Framers are relevant to the determination of constitutional meaning.

\section{ORIGINALISM AND INCORPORATION}

The holding of District of Columbia v. Heller establishes that the Second Amendment limits federal power to regulate weapons. Although Heller itself involved a statute enacted by the government of the District of Columbia, its rationale clearly extends to statutes enacted by Congress. Heller did not and could not decide the question of whether the right to keep and bear arms operates as a constitutional limit on the states. In contrast to the relative paucity of precedent on the substantive meaning of the

\footnotetext{
${ }^{141} I d$. at 2861 ("As previously noted, there is general agreement among the Members of the Court that the principal (if not the only) purpose of the Second Amendment is found in the Amendment's text: the preservation of a 'well regulated Militia."').

142 E.g., id. at 2822 (stating "[t]he text of the Amendment . . . provide[s] a clear answer"); id. ("Neither the text of the Amendment nor the arguments advanced by its proponents evidenced the slightest interest in limiting any legislature's authority to regulate private civilian uses of firearms."); id. at 2823 (arguing on the basis of "the most natural reading of the Amendment's text").
} 
Second Amendment, the question of whether the Amendment applies to the states would require the Supreme Court to consider a long and tangled body of precedent, including the Court's infamous decision in United States v. Cruikshank, ${ }^{143}$ holding that the Second Amendment did not apply to the states. ${ }^{144}$

What does Heller have to say about the question of incorporation? ${ }^{145}$ Answering this question can proceed in two steps-beginning with Heller's dictum on incorporation and proceeding to a more detailed investigation of the implications of originalism for incorporation of the Bill of Rights via the Due Process Clause of the Fourteenth Amendment. The next step implicates one of the Constitution's lost clauses, the Privileges or Immunities Clause.

\section{A. Heller's Dictum on Incorporation}

Footnote 23 of the majority opinion in Heller contains the following brief dictum on the question of incorporation:

With respect to Cruikshank's continuing validity on incorporation, a question not presented by this case, we note that Cruikshank also said that the First Amendment did not apply against the States and did not engage in the sort of Fourteenth Amendment inquiry required by our later cases. Our later decisions in Presser v. Illinois, and Miller v. Texas, reaffirmed that the Second Amendment applies only to the Federal Government. ${ }^{146}$

\footnotetext{
14392 U.S. 542, 553 (1875); see also Miller v. Texas, 153 U.S. 535, 538 (1894); Presser v. Illinois, 116 U.S. 252, 264-65 (1886).

144 See generally Michael Anthony Lawrence, Second Amendment Incorporation through the Fourteenth Amendment Privileges or Immunities and Due Process Clauses, 72 Mo. L. ReV. 1 (2007). On incorporation and the application of the Bill of Rights to the states in general, see, for example, AMAR, The Bill of Rights, supra note 44; Michael Kent Curtis, No State Shall Abridge: The FourteEnth AMENDMENT AND the Bill of Rights (1986); Richard L. Aynes, Constricting the Law of Freedom: Justice Miller, the Fourteenth Amendment, and the Slaughter-House Cases, 70 CHI.-KenT L. REV. 627 (1994); William Winslow Crosskey, Charles Fairman, "Legislative History," and the Constitutional Limitations on State Authority, 22 U. CHI. L. REV. 1 (1954); Michael Kent Curtis, Resurrecting the Privileges or Immunities Clause and Revising the Slaughter-House Cases Without Exhuming Lochner: Individual Rights and the Fourteenth Amendment, 38 B.C. L. Rev. 1 (1996); Charles Fairman, Does the Fourteenth Amendment Incorporate the Bill of Rights?, 2 STAN. L. REV. 5 (1949); Felix Frankfurter, Memorandum on "Incorporation" of the Bill of Rights into the Due Process Clause of the Fourteenth Amendment, 78 HARV. L. Rev. 746 (1965); John Harrison, Reconstructing the Privileges or Immunities Clause, 101 YALE L.J. 1385 (1992); Jerold H. Israel, Selective Incorporation: Revisited, 71 GEO. L.J. 253 (1982); Clarence Thomas, The Higher Law Background of the Privileges or Immunities Clause of the Fourteenth Amendment, 12 HARV. J.L. \& PUB. POL'Y 63 (1989).

145 On the relationship between originalism and incorporation, see generally Lawrence B. Solum, Incorporation and Originalism Theory (Illinois Pub. Law Research Paper No. 08-16, 2009), available at http://papers.ssrn.com/sol3/papers.cfm?abstract_id=1346453.

${ }^{146}$ Heller, 128 S. Ct. at 2813 n.23 (citing Presser, 116 U.S. at 265, and Miller, 153 U.S. at 538 (1894)).
} 
This footnote takes no explicit position on whether the Second Amendment applies to the states, but it includes two implied criticisms of the outcome in Cruikshank. First, it notes that Cruikshank suggested the Fourteenth Amendment did not overrule Barron ex rel. Tiernan v. Mayor of Baltimore, which had held that the Bill of Rights did not apply to the states. ${ }^{147}$ This aspect of Cruickshank is no longer good law. Second, the footnote mentions that Cruickshank "did not engage in the sort of Fourteenth Amendment inquiry required by our later cases.” That inquiry has resulted in the incorporation of most of the provisions of the Bill of Rights via the Due Process Clause of the Fourteenth Amendment.

Viewed from the perspective of contemporary constitutional doctrine, the question of incorporation seems relatively straightforward. Provisions of the Bill of Rights are incorporated if they are "fundamental," and Heller itself suggests that the right to keep and bear arms is "fundamental." 148 Of course, an argument could be made that the prefatory clause indicates that the purpose of the Second Amendment was to limit the power of Congress, but that same argument applies with even greater force to the First Amendment, which is explicitly phrased as a limitation of Congress.

Heller does not decide the incorporation question, but both the dictum in footnote 23 and the opinion's originalist methodology have implications for the decision whether the "right to keep and bear arms" applies to the states. Although it is possible to read Heller as coming close to endorsing incorporation of the Second Amendment via the Due Process Clause, the logic of the opinion points in the direction of a more radical alternativethe resurrection of the Privileges or Immunities Clause of the Fourteenth Amendment.

\section{B. Privileges or Immunities Versus Due Process}

If the question of incorporation seems straightforward as a matter of contemporary constitutional doctrine, it becomes complicated when viewed from the perspective of originalist theory. Mark Tushnet puts the issue succinctly:

[T]he next step will be litigation challenging state and local gun control regulations, in which the first issue will be whether the Fourteenth Amendment makes the restrictions the Second Amendment imposes on the national government applicable to the states as well. On originalist grounds, such an "incorporation" seems to me unquestionably correct. The debates over the Fourteenth Amendment's adoption are replete with comments that one of the Amendment's benefits would be to ensure that the South's freedmen would be able to protect themselves from marauding whites by guaranteeing their own right to arm themselves. The only embarrassment is a doctrinal one: all these

\footnotetext{
14732 U.S. (7 Pet.) 243 (1833).

148 Heller, 128 S. Ct. at 2798 ("By the time of the founding, the right have arms had become fundamental for English subjects.”).
} 
references described the right to keep and bear arms as one of the privileges of the citizenship that the Fourteenth Amendment guaranteed, and contemporary incorporation doctrine rests not on the privileges or immunities clause of the Fourteenth Amendment, but rather on its due process clause. ${ }^{149}$

In this Article, my aim is neither to affirm or deny Professor Tushnet's contention that incorporation of the Second Amendment via the Privileges or Immunities Clause is "unquestionably correct" on "originalist grounds." 150 Instead, my focus is on the implications of the incorporation issue for originalist theory.

If our only concerns were consequentialist, it might be argued that the difference between incorporation under the Due Process Clause, on the one hand, or the Privileges or Immunities Clause, on the other, is relatively insubstantial. There is one significant practical difference between the two clauses. The Due Process Clause applies to all "persons," whereas the Privileges or Immunities Clause applies only to "citizens." Neither permanent resident aliens nor undocumented workers would be afforded the "right to keep and bear arms" if the right were applied to the states via the Privileges or Immunities Clause of the Fourteenth Amendment. Whatever its status under American constitutional law, the right to keep and bear arms is not viewed as a fundamental human right. Moreover, the gun control laws that are invalidated under the Second Amendment might not be retained by state and local governments if their only constitutionally valid domain of application was limited to noncitizens. ${ }^{151}$

\section{Implications of Incorporation for Originalism and Stare Decisis}

The practical implications of the choice between due process and privileges or immunities may be de minims, but viewed from the perspective of originalist theory, the choice of the mode of incorporation is arguably an issue of the highest order of constitutional importance. Unlike Heller, where the majority believed that the sparse precedent on the substantive meaning of the Second Amendment was easily distinguishable, there are three Supreme Court precedents that squarely hold against application of the Second

\footnotetext{
149 Mark Tushnet, The Future of the Second Amendment, 1 ALB. Gov'T L. REV. 354, 355 n.4 (2008).

150 See Lawrence, supra note 144, for a contemporary discussion. On the general question whether the Privileges or Immunities Clause supports incorporation of the provisions of the Bill of Rights, see Michael Kent Curtis, The Bill of Rights and the States: An Overview From One Perspective J. CONTEMP. LEGAL ISSUES (forthcoming 2009), available at http://ssrn.com/abstract=1334687; Michael Kent Curtis, Historical Linguistics, Inkblots, and Life after Death: The Privileges or Immunities of Citizens of the United States, 78 N.C. L. REV. 1071 (2000).

151 The question exists whether failure to extend the right to bear arms to noncitizens would have practical significance. One might believe that it would be unlikely that many states or localities would retain otherwise unconstitutional gun control laws for noncitizens. On the other hand, one can imagine that xenophobia might operate with particular virulence with respect to the possession of weapons by noncitizens. I owe thanks to William Baude for discussion of this point.
} 
Amendment to the states. Of course, these precedents have themselves been undermined by subsequent decisions holding that fundamental rights conferred by the Bill of Rights are incorporated in the Due Process Clause of the Fourteenth Amendment. ${ }^{152}$

The precedents that established the doctrine of selective incorporation under the Due Process Clause are themselves subject to an originalist critique. If the Court asks the question of whether the incorporation of fundamental substantive rights is supported by the original public meaning of the Due Process Clause, the answer may well be "no." The question would concern the conventional semantic meaning of the phrase "due process of law" in light of usage during the Reconstruction era. If the answer to that question limits the clause to what is now called "procedural due process," then incorporation of the Second Amendment via the Due Process Clause might be unsupportable on originalist grounds.

It would be open to the Court to resolve the conflict between original public meaning and precedent in favor of the latter. The Court could determine that original public meaning must give way to the doctrine of stare decisis. If, however, the Court were to adopt this course, it would mean that the bold originalist pronouncements in Heller would potentially offer little or nothing in the way of generative force. The Second Amendment may not be the only provision of the Constitution where the Court could write with an originalist pen on a blank slate, ${ }^{153}$ but if originalism is limited to these rare cases of unconstrained inscription, then originalist constitutional interpretation is likely to have very little to say about the most important constitutional controversies of our age. Those controversies include federalism, separation of powers, the freedoms of speech and religion, the rights of criminal defendants, and the implied fundamental right to privacy, all constitutional domains one could not fairly characterize as "blank slates.” It is possible to imagine a scenario where Heller results in a Second Amendment incorporation decision that affirms the primacy of precedent over original meaning. Should this scenario come to pass, the ultimate effect of Heller might be to undermine rather than advance constitutional originalism in practice.

There are, however, at least two alternative scenarios. One of these involves incorporation of the right to keep and bear arms under the Privileges or Immunities Clause, and the implications of that scenario are examined below. ${ }^{154}$ The other scenario involves the possibility that the Court will incorporate the right to keep and bear arms under the Due Process Clause but explicitly cabin the circumstances under which nonoriginalist precedent is allowed to trump original meaning. For example, the Court might maintain

\footnotetext{
152 For examples of these precedents, see Frankfurter, supra note 144.

153 See Lawrence B. Solum, Originalism and the Natural Born Citizen Clause, 107 Mich. L. REV. FIRST IMPRESSIONS 22 (2008), http://www.michiganlawreview.org/firstimpressions/vol107/solum.htm.

154 See infra Part IV.D.
} 
that the due process incorporation decisions are insulated from overruling on originalist grounds because they are deeply embedded in constitutional law in at least three ways: (1) they extend over a period of many decades; (2) a large number of decisions joined by many different members of the Court explicitly affirm the doctrine; and (3) a very large number of other decisions in a wide variety of doctrinal areas are premised on the validity of incorporation under the Due Process Clause.

Of course, these criteria are met by much of the Court's New Deal jurisprudence. For example, it might be argued that the Court's federalism jurisprudence shares these characteristics: (1) the Court has embraced an expansive view of federal power for approximately seventy years; (2) there are a large number of decisions that explicitly reject federalism challenges to a wide variety of federal statutes; and (3) an even larger number of Supreme Court decisions assume the validity of post-New Deal legislation that arguably exceeds the power conferred by the original public meaning of the Commerce Clause.

There are, however, significant regions of constitutional doctrine that might not satisfy these criteria- or similar criteria that might cabin the due process incorporation precedents. One clear example is the Supreme Court's decision in Lawrence v. Texas, ${ }^{155}$ which is relatively recent, has not been explicitly affirmed by any subsequent decisions of the Supreme Court, and has not served as the implicit foundation for any other Supreme Court decisions. Because Heller was a 5-4 decision with Justice Kennedy in the majority and because Kennedy was the author of Lawrence, one could speculate that he would be reluctant to join any opinion that would undermine the validity of Lawrence. ${ }^{156}$

\section{Privileges or Immunities and Original Public Meaning}

This brings us to the final scenario. It would certainly be open to the Court to rest incorporation of the right to keep and bear arms on the Privileges or Immunities Clause of the Fourteenth Amendment. Once again, precedent (in the form of the Slaughter-House Cases $^{157}$ ) might create an obstacle to incorporation. But since incorporation under the Due Process Clause is deeply embedded in existing doctrine, overruling SlaughterHouse would not have a disruptive effect and would likely meet the criteria articulated in Planned Parenthood of Southeastern Pennsylvania v. Casey. ${ }^{158}$ The relevant paragraphs from Casey are quoted in full in the footnote accompanying this text. ${ }^{159}$

\footnotetext{
155539 U.S. 558 (2003).

${ }^{156}$ It is possible that Lawrence might be regrounded on the Privileges or Immunities Clause: this Article takes no position on that issue.

15783 U.S. 36 (1873).

158505 U.S. 833 (1992).

159 Id. at 854-55 (citations omitted):
} 
This option has at least superficial appeal for originalists. There may be substantial evidence that the Reconstruction Representatives and Senators who drafted and proposed the Fourteenth Amendment intended and expected the Privileges or Immunities Clause to incorporate the Bill of Rights in general and the Second Amendment right to keep and bear arms in particular. ${ }^{160}$ If incorporation of the Second Amendment were accomplished via the Privileges or Immunities Clause, it might establish a precedent that would allow the Court to gradually shift the basis for incorporation of other provisions of the Bill of Rights from due process to privileges or immunities. That development would undermine a significant objection to originalism-that it is inconsistent with the application of the First Amendment and the other provisions of the Bill of Rights to the states, and hence is unacceptably radical in its implications. If the Second Amendment were incorporated via the Privileges or Immunities Clause, then it might become clear that originalists could support the incorporation of the other provisions of the Bill of Rights.

Shifting the basis for incorporation from due process to privileges or immunities would suggest a growing role for originalist methodology in constitutional practice. Incorporation has pervasive effects because it is the basis for huge swaths of modern individual rights jurisprudence. If Heller were followed by an originalist opinion that rested incorporation of the Second Amendment on the Privileges and Immunities Clause, and if that decision prompted a general shift in incorporation doctrine, a tipping point

The obligation to follow precedent begins with necessity, and a contrary necessity marks its outer limit. With Cardozo, we recognize that no judicial system could do society's work if it eyed each issue afresh in every case that raised it. Indeed, the very concept of the rule of law underlying our own Constitution requires such continuity over time that a respect for precedent is, by definition, indispensable. At the other extreme, a different necessity would make itself felt if a prior judicial ruling should come to be seen so clearly as error that its enforcement was, for that very reason, doomed.

Even when the decision to overrule a prior case is not, as in the rare, latter instance, virtually foreordained, it is common wisdom that the rule of stare decisis is not an "inexorable command," and certainly it is not such in every constitutional case. Rather, when this Court reexamines a prior holding, its judgment is customarily informed by a series of prudential and pragmatic considerations designed to test the consistency of overruling a prior decision with the ideal of the rule of law, and to gauge the respective costs of reaffirming and overruling a prior case. Thus, for example, we may ask whether the rule has proven to be intolerable simply in defying practical workability; whether the rule is subject to a kind of reliance that would lend a special hardship to the consequences of overruling and add inequity to the cost of repudiation; whether related principles of law have so far developed as to have left the old rule no more than a remnant of abandoned doctrine; or whether facts have so changed, or come to be seen so differently, as to have robbed the old rule of significant application or justification.

So in this case, we may enquire whether Roe's central rule has been found unworkable; whether the rule's limitation on state power could be removed without serious inequity to those who have relied upon it or significant damage to the stability of the society governed by it; whether the law's growth in the intervening years has left Roe's central rule a doctrinal anachronism discounted by society; and whether Roe's premises of fact have so far changed in the ensuing two decades as to render its central holding somehow irrelevant or unjustifiable in dealing with the issue it addressed.

160 For a review of the evidence, see Lawrence, supra note 144. 
might be reached. It is at least imaginable that judges and scholars would routinely discuss the original public meaning of the constitutional text as a routine step in constitutional analysis.

A general shift to incorporation under the Privileges or Immunities Clause, however, would create its own problems for originalists. As noted above, the Privileges or Immunities Clause confers rights only on citizens. That limitation might or might not pose a serious problem in the context of the Second Amendment, ${ }^{161}$ but denying freedom of speech, free exercise, or the right against cruel and unusual punishment to noncitizens would pose fundamental questions about respect for human rights. It should not be assumed, though, that withdrawal of federal constitutional protection for these rights would leave them without any protection at all. State constitutions could provide independent protection for rights of this sort. ${ }^{162}$ Constitutional rules that only apply to citizens could create norms internalized by state and local officials that would provide roughly equivalent nonlegal rights for noncitizens. Finally, it is possible that the core of incorporated rights might be extended to noncitizens via the Equal Protection Clause, at least in cases in which state or local law makes an explicit distinction between citizens and noncitizens. ${ }^{163}$

Shifting the basis of incorporation to the Privileges or Immunities Clause might have other consequences in the long run. Original public meaning originalism looks to the conventional semantic meaning-the clause meaning - of the text. In the case of the Privileges or Immunities Clause, the text is seemingly opaque. Section One of the Fourteenth Amendment reads in full:

All persons born or naturalized in the United States, and subject to the jurisdiction thereof, are citizens of the United States and of the State wherein they reside. No State shall make or enforce any law which shall abridge the privileges or immunities of citizens of the United States; nor shall any State deprive any person of life, liberty, or property, without due process of law; nor deny to any person within its jurisdiction the equal protection of the laws. ${ }^{164}$

Thus, the operative clause language of the Privileges or Immunities Clause is:

No State shall make or enforce any law which shall abridge the privileges or immunities of citizens of the United States.

For original public meaning originalists, the question is: What are the "privileges or immunities" granted or recognized by the Amendment? Us-

\footnotetext{
161 See supra Part IV.B.

162 See Carreras v. City of Anaheim, 768 F.2d 1039 (9th Cir. 1985) (applying California’s liberty of speech clause).

163 This assumes that the original meaning of the Equal Protection Clause would be consistent with this result. That question is outside the scope of this Article.

164 U.S. CONST. amend. XIV.
} 
ing the language of Heller, the question is: What was the "normal and ordinary as distinguished from technical meaning" of the words "privilege" and "immunity" or the phrase "privileges or immunities of citizens?"

The point of this inquiry is not to answer that question because an answer would require research into patterns of usage in the Reconstruction Era. My impression of the literature ${ }^{165}$ is that most of the writing about the Privileges or Immunities Clause from an originalist perspective relies heavily on evidence of the purposes and expectations of those who participated in drafting and proposing the Fourteenth Amendment. That evidence is relevant to the conventional semantic meaning of the words and phrases, but it is not direct evidence of original public meaning.

This raises a possibility that some originalists might find disquieting. It is at least possible that the phrase "privileges or immunities of citizens of the United States" would have been radically ambiguous or even unfathomable to ordinary citizens at the time the Fourteenth Amendment was proposed and ratified. Linguistic intuitions may vary, but it is the sense of the author that this phrase would be ambiguous (or even opaque) today to ordinary readers-those without specialized knowledge of the Constitution. The possibility exists, however, that the phrase did have an idiomatic meaning during the Reconstruction Era that would be revealed by analysis of evidence of ordinary usage, such as in newspapers, diaries, and similar sources. If original public meaning originalists are truly committed to the proposition that it is the "normal and ordinary as distinguished from technical meaning" that determines the clause meaning of the Constitution, then it might be the case that the Privileges or Immunities Clause would be meaningless or radically ambiguous - that it would have no meaning at all or have several different meanings.

How should originalist theory respond to the possibility that a given clause might lack "normal and ordinary as distinguished from technical meaning?” One possibility would be to deploy the interpretationconstruction distinction ${ }^{166}$ when constitutional interpretation yields residual ambiguity-ambiguity that isn't clarified by the publicly available context of constitutional utterance. ${ }^{167}$ If originalist theory requires this result, then it might undermine one of the normative justifications sometimes offered for originalism - that it constrains judicial discretion and reinforces the rule of law. ${ }^{168}$ Because theories of constitutional construction are outside the domain of originalism as a theory of constitutional interpretation, this objection can only be assessed in the context of a particular theory of constitutional construction. Some theories of construction might recreate

165 See supra note 144 (citing literature on incorporation).

166 See supra Part I.E (discussing Barnett and Whittington on the distinction between constitutional interpretation and constitutional construction).

167 See Solum, supra note 66, pt. III.C.2.

168 See id. pt. IV.B.2. 
the problem of unconstrained judicial discretion, but others might not. For example, if constitutional construction is relegated to the political branches, then the judicial discretion problem would vanish; likewise, a theory of constitutional construction that incorporates a strong doctrine of stare decisis might ameliorate the problem of discretion. ${ }^{169}$

There is, however, another option open to original public meaning originalism. Where a word or phrase lacks a "normal and ordinary" meaning, then the public meaning of the provision might be provided by a division of linguistic labor ${ }^{170}$ that assigns linguistic responsibility for "terms of art" to specialized subgroups of language users. Blackstone put it this way: terms of art "must be taken according to the acceptation of the learned in each art, trade, and science.”171

When a member of the public at large encounters a constitutional term of art her understanding of its meaning may involve a process of deferral. Consider the following example: an ordinary citizen reads the phrase "letters of marque and reprisal," and thinks, "Hmm. I wonder what that means. It sounds like technical legal language to me. If I want to know what it means, I should probably ask a lawyer." Accordingly, ordinary citizens would recognize a division of linguistic labor and would defer understanding of the term of art to those who were members of the relevant group and those who shared the understandings of the members of the relevant group.

This solution requires either that each constitutional term of art refer us to a single group, or to a group of groups that share the same understanding of the term of art. For example, if both sailors and lawyers shared the same understanding of "letters of marque and reprisal" then constitutional communication could succeed. If different groups had different understandings of the same phrase, constitutional communication could still succeed, assuming the publicly available context of constitutional utterance allowed resolution of the resulting ambiguity.

In the case of the Privileges or Immunities Clause of the Fourteenth Amendment, the relevant possibility is that the phrase "privileges or immunities" was a term of art, which had a shared meaning among the relevant group of specialists - those learned in the law. For example, the following passage in Blackstone is suggestive of the possibility that the words "privilege" and "immunity" were terms of art:

\footnotetext{
169 See Solum, supra note 91.

170 The idea of a division of linguistic labor is usually attributed to Hilary Putnam. See HILARY Putnam, The Meaning of 'Meaning,' in 2 Philosophical PaPers: Mind, LANGUAGE AND Reality 215 (1975); see also Robert Ware, The Division of Linguistic Labor and Speaker Competence, 34 Philosophical StUdies 37 (1978); Mark Greenberg, Incomplete Understanding, Deference, and the Content of Thought (UCLA School of Law Pub. Law \& Legal Theory Research Paper Series, Research Paper No. 07-30, 2007), available at http://ssrn.com/abstract=1030144.

1711 WiLLIAM BLACKSTONE, COMMENTARIES *59.
} 
Thus much for the declaration of our rights and liberties. The rights themselves thus defined by [Magna Carta and other foundational] statutes, consist in a number of private immunities; which will appear, from what has been premised, to be indeed no other, than either that residuum of natural liberty, which is not required by the laws of society to be sacrificed to public convenience; or else those civil privileges, which society hath engaged to provide, in lieu of the natural liberties so given up by individuals. These therefore were formerly, by inheritance or purchase, the rights of all mankind; but, in most other countries of the world being now more or less debased and destroyed, they at present may be said to remain, in a peculiar and emphatical manner, the rights of the people of England. And these may be reduced to three principal or primary articles; the right of personal security, the right of personal liberty; and the right of private property: because as there is no other known method of compulsion, or of abridging man's natural free will, but by an infringement or diminution of one or other of these important rights, the preservation of these, inviolate, may justly be said to include the preservation of our civil immunities in their largest and most extensive sense declaration of our rights and liberties. ${ }^{172}$

Or the famous passage from Corfield $v$. Coryell ${ }^{173}$ might provide the relevant technical meaning:

The inquiry is, what are the privileges and immunities of citizens in the several states? We feel no hesitation in confining these expressions to those privileges and immunities which are, in their nature, fundamental; which belong, of right, to the citizens of all free governments; and which have, at all times, been enjoyed by the citizens of the several states which compose this Union, from the time of their becoming free, independent, and sovereign. What these fundamental principles are, it would perhaps be more tedious than difficult to enumerate. They may, however, be all comprehended under the following general heads: Protection by the government; the enjoyment of life and liberty, with the right to acquire and possess property of every kind, and to pursue and obtain happiness and safety; subject nevertheless to such restraints as the government may justly prescribe for the general good of the whole. The right of a citizen of one state to pass through, or to reside in any other state, for purposes of trade, agriculture, professional pursuits, or otherwise; to claim the benefit of the writ of habeas corpus; to institute and maintain actions of any kind in the courts of the state; to take, hold and dispose of property, either real or personal; and an exemption from higher taxes or impositions than are paid by the other citizens of the state; may be mentioned as some of the particular privileges and immunities of citizens, which are clearly embraced by the general description of privileges deemed to be fundamental: to which may be added,

\footnotetext{
172 Id. at *125 (emphasis added); see also Eric R. Claeys, Blackstone’s Commentaries and the Privileges or Immunities of United States Citizens: A Modest Tribute to Professor Siegan, SAN DIEGO L. REV. (forthcoming 2008), available at http://papers.ssrn.com/sol3/papers.cfm?abstract_id=1101792.

1736 F. Cas. 546 (C.C.E.D. Pa. 1823) (No. 3230).
} 
the elective franchise, as regulated and established by the laws or constitution of the state in which it is to be exercised. ${ }^{174}$

Just as the best evidence of public meaning is ordinary discourse as revealed by nonspecialized sources, such as newspapers or diaries, the best evidence of a term of art would be the writings of those specialized in the art-judges, lawyers, public officials, and others learned in the law. Once again, the aim would be to establish patterns of usage that revealed a conventional semantic meaning among the members of the relevant subgroup of language users.

The purpose of this inquiry is not to determine the meaning of the Privileges or Immunities Clause-that project is far beyond the scope of this Article. Nonetheless, our cursory examination of two prominent sources suggests that the phrase "privileges or immunities" might have been understood by the relevant subgroup of language users as referring to natural rights and those legally created rights that substitute for natural rights. If this were the case, the implications for the Supreme Court's unenumerated rights jurisprudence could be profound.

\section{E. Privileges or Immunities and Unenumerated Rights}

Suppose the Second Amendment were incorporated via the Privileges or Immunities Clause of the Fourteenth Amendment and the Court adopted the division of linguistic labor theory to resolve the problem of ambiguity concerning the "normal and ordinary as distinguished from technical meaning" of the phrase "privileges or immunities of citizens of the United States." What consequences might this have for the Court's unenumeratedrights jurisprudence?

Of course, this is a very large question. One possibility is that an original public meaning approach to the Privileges and Immunities Clause would result in a substantial reconfiguration of the implied fundamental rights doctrine. ${ }^{175}$ For example, if Blackstone's identification of "private immunities" with "natural rights" (or something like it) provided the relevant understanding of "immunities" as a term of art, then originalists would be committed to natural rights jurisprudence, a development that might be welcomed by some and strongly resisted by others.

Moreover, the turn to the Privileges or Immunities Clause might result in a substantial reconfiguration of the debate over Roe v. Wade. Although one prominent commentator has suggested that "Roe $v$. Wade is a particular target of originalist ire” and that "the right of privacy is generally objection-

\footnotetext{
174 Id. at 551-52.

175 See Barnett, supra note 78, at 23 ("Does the text protect only enumerated rights, or does it also insist that other rights not be denied or disparage? Does the Fourteenth Amendment protect a specific list of liberties debated at the time from infringement by states, or did it protect all 'privileges or immunities of citizenship'?”).
} 
able on originalist grounds, ${ }^{176}$ these conclusions are not clear given an original public meaning approach to the Privileges or Immunities Clause. Regarding Roe itself, one argument noted by Barnett, is that Roe might be reaffirmed under the Privileges or Immunities Clause:

[T] he original public meaning of Section 1 of the Fourteenth Amendment is gender neutral. To apply it to particular cases requires the identification of those privileges or immunities enjoyed by all citizens, regardless of gender. And this would include, I would maintain, the natural right to control one's body, including one's reproductive processes, even against a competing moral concern for the unborn who, at least in the early stages of pregnancy, are neither "citizens" nor "persons" under the original meaning of the Constitution. ${ }^{177}$

Once again, the point of this discussion is not to take a position on the implications of the Privileges and Immunities Clause for Roe v. Wade. Instead, the aim of this inquiry is to demonstrate the possibilities for Heller to ramify through the seamless web of the law. ${ }^{178}$

Heller's implications for constitutional theory and practice are still far from certain. Although the majority's strong and clear endorsement of originalist methodology might be read as a turning point in constitutional jurisprudence, confirmation of that reading will require evidence that Heller has generative force- the power to influence both the future decisions of the Supreme Court and the constitutional practice by lower court judges, officials, and citizens. The most powerful vehicle for the extension of Heller's influence is the Privileges or Immunities Clause of the Fourteenth Amendment. Resting incorporation on that clause would open the door to the application of originalist principles to a wide variety of constitutional issues, potentially extending the influence of Heller far beyond "the right to keep and bear arms.”

\section{HELLER AND THE INTERPRETATION-CONSTRUCTION DISTINCTION}

The distinction between constitutional interpretation and constitutional construction is characteristic of recent academic work in the tradition of the

\footnotetext{
176 Cass R. Sunstein, Burkean Minimalism, 105 Mich. L. REV. 353, 391 (2006).

177 Randy E. Barnett, Underlying Principles, 24 Const. COMM. 405, 415 (2007).

178 On the seamless web, see F.W. Maitland, A Prologue to a History of English Law, 14 L.Q.R. 13 (1898) ("Such is the unity of all history that any one who endeavours to tell a piece of it must feel that his first sentence tears a seamless web.”). See also Transworld Airlines v. Am. Coupon Exch., 913 F.2d 676, 685 (9th Cir. 1990) (Reinhardt, J.) (discussing “law’s oft-proclaimed seamless web”); Kleinwort Benson Ltd. v. Lincoln City Council, (1998) 2 A.C. 349, 378 (H.L.) (Lord Goff of Chieveley) ("This means not only that he must act within the confines of the doctrine of precedent, but that the change so made must be seen as a development, usually a very modest development, of existing principle and so can take its place as a congruent part of the common law as a whole. In this process, what Maitland has called the 'seamless web', and I myself called the 'mosaic', of the common law, is kept in a constant state of adaptation and repair, the doctrine of precedent, the 'cement of legal principle, providing the necessary stability.”) (citation ommited).
} 
New Originalism. ${ }^{179}$ Does that distinction shed light on the role of originalist theory in the Heller decision? What are the implications of the distinction between interpretation and construction for the Second Amendment litigation that is sure to follow Heller?

\section{A. The Puzzling Passage in Heller}

Before I explicate the interpretation-construction distinction itself, let's take a look at a curious passage in the majority opinion in Heller:

Although we do not undertake an exhaustive historical analysis today of the full scope of the Second Amendment, nothing in our opinion should be taken to cast doubt on longstanding prohibitions on the possession of firearms by felons and the mentally ill, or laws forbidding the carrying of firearms in sensitive places such as schools and government buildings, or laws imposing conditions and qualifications on the commercial sale of arms. ${ }^{180}$

From a practical point of view, this passage is unremarkable. The Court simply seems to be enunciating some common sense limitations on the holding. What is puzzling about this passage is that it seems unconnected to the originalist methodology that formed the basis of the main holding in Heller - that a ban on handgun ownership violated an individual right to possess and carry weapons.

That holding had been justified by a meticulous discussion of the meaning of each operative word and phrase in the Second Amendment at the time it was adopted. In each case, the Court cited evidence of usage around the time the amendment was framed, proposed, and ratified, but no such evidence is cited to justify the various limits on the right mentioned in the passage. In response, the legal philosopher Brian Leiter has commented:

Now how is this out-of-whole-cloth set of limitations on the right to be squared with the interpretive principle that "words and phrases were used in their normal and ordinary as distinguished from technical meaning" and that "normal meaning . . . include[s] idiomatic meaning, but . . . excludes secret or technical meanings that would not have been known to ordinary citizens in the founding generation"? 181

Various explanations could clarify why the majority included this puzzling passage. One possibility is that this passage was added at the behest of one of the other Justices (perhaps Justice Kennedy) and is truly a "sore thumb"-inserted only for the purpose of garnering a fifth vote and not on

\footnotetext{
${ }^{179}$ For an analysis of the issues discussed in this Part that does not employ the terminology of the interpretation-construction distinction, see Denning, The New Doctrinalism, supra note 6.

${ }^{180}$ District of Columbia v. Heller, 128 S. Ct. 2783, 2816-17 (2008).

181 Brian Leiter, A Puzzle About Heller, Brian Leiter's Legal Philosophy Blog, June 27, 2008, http://leiterlegalphilosophy.typepad.com/leiter/2008/06/a-puzzle-about.html (quoting Heller, 128 S.Ct. at 2788).
} 
the basis of any principled reason of originalist theory. But there is another possibility. It may be that the kinds of restrictions that are briefly mentioned stem from a different constitutional methodology that is consistent with, but distinct from, originalist constitutional interpretation; that is, Heller's dicta may involve constitutional construction.

\section{B. Two Distinctions: Interpretation-Construction and Ambiguity-Vagueness}

What is the difference between "constitutional interpretation" and "constitutional construction?"182 Absent a thorough familiarity with the history of the law of contracts, trusts, or wills, or a deep knowledge of contemporary constitutional theory, some readers may assume that these two terms are synonyms. Many authors use "interpretation" and "construction" more or less interchangeably. ${ }^{183}$ In fact, the distinction between interpretation of the linguistic meaning of legal texts and the construction of legal rules from that linguistic meaning has a long history in Anglo-American law. ${ }^{184}$ Here is a first, rough cut at definitions that mark the distinction:

Interpretation: The activity of determining the linguistic meaning-or semantic content-of a legal text.

Construction: The activity of translating the semantic content of a legal text into legal rules, paradigmatically in cases where the meaning of the text is vague.

We interpret the meaning of a text, and then we construct legal rules to help us apply the text to particular fact situations.

Courts and legal theorists use the distinction between interpretation and construction in a variety of legal contexts, including contract law. In a contracts case, for example, the Iowa Supreme Court stated, "Interpretation involves ascertaining the meaning of contractual words; construction refers to deciding their legal effect.”185

\footnotetext{
182 See generally Mark K. Glasser \& Keith A. Rowley, On Parol: The Construction and Interpretation of Written Agreements and the Role of Extrinsic Evidence in Contract Litigation, 49 BAYLOR L. REV. 657, 661-63 (1997); Note, Choice-of-Law Rules for the Construction and Interpretation of Written Instruments, 72 HARV. L. REV. 1154 (1959).

183 See, e.g., Bryan A. Garner, A Dictionary of Modern Legal Usage 462 (2d ed. 1995); Michael W. Mullane, Statutory Interpretation in Arkansas: How Should a Statute be Read? When Is It Subject to Interpretation? What Our Courts Say and What They Do, 2004 ARK. L. NOTES 85, 89 n.22 (2004) (“'Interpretation' and 'construction' will be treated as synonyms in this paper.”); Gary E. O’Connor, Restatement (First) of Statutory Interpretation, 7 N.Y.U. J. LEGIS. \& PUB. POL'Y 333, 335 n.5 (2004) ('This article treats the terms 'statutory interpretation' and 'statutory construction' as interchangeable synonyms.”).

184 See Francis Lieber, Legal AND Political HeRmeneUtics 11, 44 (1880).

185 Fashion Fabrics of Iowa v. Retail Investors Corp., 266 N.W.2d 22, 25 (Iowa 1978).
} 
The interpretation-construction distinction is related to another distinction that is important for the New Originalists - the distinction between vagueness and ambiguity. ${ }^{186}$ A word, phrase, sentence, or clause is ambiguous if it has more than one sense. The word "cool," for example, is ambiguous because it can mean (a) hip, (b) of low temperature, or (c) of even temperament. A word or phrase is vague when it has borderline cases. The word "tall" is vague because there is no bright line between those individuals who are tall and those who are not. The same word can be both ambiguous and vague in one or more of its senses: cool is ambiguous and each sense of cool is vague. ${ }^{187}$

Characteristically, interpretation resolves ambiguity and construction creates subsidiary rules that resolve vagueness. In most cases, interpretation resolves ambiguity because usually there is a linguistic fact of the matter about the semantic meaning of a text given the context of utterance: words that are ambiguous without context usually become unambiguous once the context of utterance is considered.

The relationship between ambiguity, context, and interpretation can be clarified by examples. The word "cool" is ambiguous, but in the context, "That refrigerator is running very cool-let's check the thermostat," the ambiguity disappears. Likewise, if someone says, "Miles Davis was a pioneer of cool jazz," we know that the intended sense is not temperature related. This same point can be illustrated with examples from constitutional law. For example, the phrase "United States" in the United States Constitution refers to the nation composed of fifty states in North American and various territories; it does not refer to other political entities that have been called the United States, such as the United States of Belgium, the United States of Mexico, or the United States of Brazil.

Characteristically, interpretation resolves ambiguity, but in the usual case, construction resolves vagueness. Interpretation is inapt as a method for resolving vagueness, because interpretation (the determination of linguistic meaning or semantic content) cannot do the required work. When a word or phrase has a linguistic meaning that is vague, then interpretation runs out. If the linguistic meaning is vague, then vagueness is the result of interpretation and not a problem to be solved by interpretation. When interpretation exits the stage, then construction makes its entrance. Construction allows us to draw a line-making the vague provision more specificor gives us a decision procedure, such as a procedure that allows case-bycase resolution of the vagueness.

\footnotetext{
186 See E. Allan Farnsworth, “Meaning” in the Law of Contracts, 76 YALE L.J. 939, 961 (1967); Jeremy Waldron, Vagueness in Law and Language: Some Philosophical Issues, 82 CAL. L. REv. 509 (1994).

187 See generally Lawrence B. Solum, Legal Theory Lexicon 051: Vagueness and Ambiguity, Legal Theory Lexicon, Aug. 26, 2007, http://lsolum.typepad.com/legal_theory_lexicon/2006/08/legal_theory_ le.html.
} 


\section{Interpretation in Heller}

With the interpretation-construction distinction in place, we can return to the majority opinion in Heller. As we have already seen, much of the controversy in Heller concerned the relationship between the prefatory clause, "a well-regulated militia being necessary to the security of a free state" and the operative clause "the right of the people to keep and bear arms shall not be infringed." ${ }^{88}$ The essence of Justice Scalia's position is that the semantic content of the operative clause furnishes the parameters of the rule of constitutional law. The prefatory clause, according to Scalia, is like the preamble of a statute: the prefatory clause furnishes the reason for the operative clause, but it does not directly modify the semantic content of the operative clause. In this way, the prefatory clause does restrict the permissible range of interpretations of the operative clause, and thus, the semantic content of the operative clause must be such that it can be understood as serving the purpose enunciated in the prefatory clause. Justice Scalia's focus on the linguistic meaning or semantic content of the text of the Second Amendment explains his conclusion-that the Second Amendment provides for an individual right to possess and carry weapons can be understood as a mechanism by which militias are protected from federal interference.

\section{Construction in Heller}

Let us assume, for purposes of this argument, that Justice Scalia's interpretation of the operative clause in Heller was correct-that the Second Amendment forbids "infringement" of a right "to keep and bear arms" that is vested in individual persons. Is that sufficient to decide Heller? This question is crucial, and it is not quite as easy as it might seem on the surface. On the one hand, it might be argued that a ban on handgun ownership is an obvious violation of an individual right to keep and possess weapons. On the other hand, it might be argued that both "infringement" and "the right to keep and bear arms" are vague, and hence that construction is required.

Each of these two components of the operative clause deserves some additional comment. Consider first the word "infringement." Let us assume that the verb "to infringe" had at the time of the Framing a sense that seems identical or nearly identical to the modern sense, "to commit a breach or infraction of (a law, obligation, right, etc.)."189 "Infringe" in this sense is vague because there will be borderline cases in which the rule or regulation may or may not be an infringement of the right. One example of such a case is gun registration requirements. A simple registration requirement for which all citizens can easily apply with minimal cost, seems like a clear ex-

\footnotetext{
188 See supra text accompanying notes 129-134.

189 OXFORD ENGLISH DICTIONARY (2d ed. 1989).
} 
ample of a noninfringing regulation of the right to keep and possess weapons. One can imagine, however, many registration requirements that would be invalid, like, a registration scheme that requires the payment of a $\$ 10,000$ administrative processing fee. Between these points on the spectrum of burden, there will necessarily be borderline cases.

Consider next the phrase "right to keep and bear arms." Each of the operative components of this phrase may have been vague, at least in some contexts. "Keeping" involves questions about the borderlines of possession. "Bearing" involves issues at the boundary of carrying, and "arms" involves the disputed cases of "weapon." Lastly, there is the further question of what constitutes the operative concept of "right." Application of each of these terms to particular circumstances may reveal the existence of borderline cases, and if there are borderline cases, then by definition these terms are vague.

One familiar analytic framework for analyzing problems of vagueness is provided by H.L.A. Hart's metaphor of the "core" and "penumbra." 190 Vague words and phrases reveal borderline cases, but the very idea of a borderline entails that there are cases that are not in the vicinity of the border. Hart calls the disputed territory near the borderline, the "penumbra." Territory that is not in dispute is the "core." 191

One way of reading Justice Scalia's opinion in Heller might be summarized as follows:

The portion of the District of Columbia ordinance that bans possession and carrying of handguns is a core case of infringement of the right to keep and bear arms. It is infringement because a ban is the most extreme form of regulation and therefore is within the core meaning of "infringement." It regulates "arms" because handguns are within the core meaning of weapon, as confirmed by usage at the time the Second Amendment was adopted. It regulates "keeping" and "bearing" because it prohibits all or almost all possession and carrying.

On this reading of Scalia's opinion, the work in Heller was done by interpretation of the Second Amendment. Any legal rule that accurately captured the semantic content-or original public meaning —of the text would have to forbid what the District of Columbia ordinance sought to accomplish.

\footnotetext{
190 See H.L.A. HART, THE CONCEPT OF LAW (2d ed. 1994).

191 Id. at 124-36. The idea may derive from Bertrand Russell: "[A]ll words are attributable without doubt over a certain area, but become questionable within a penumbra, outside which they are again certainly not attributable.” Bertrand Russell, Vagueness, in 9 The Collected PaPers of Bertrand RusSell: EsSAYS ON LANGUAGE, Mind AND MATTER 1919-1926, at 145, 149 (John G. Slater ed., 1988).
} 


\section{E. Construction and the Disagreements Between Justice Scalia and Justice Breyer}

The dispute between Justice Breyer and Justice Scalia over standards of review and the role of balancing tests elucidates how the interpretationconstruction distinction will be relevant for the future of Second Amendment litigation. The key to understanding Breyer's opinion is the following passage:

I take as a starting point the following four propositions, based on our precedent and today's opinions, to which I believe the entire Court subscribes:

(1) The Amendment protects an "individual" right-i.e., one that is separately possessed, and may be separately enforced, by each person on whom it is conferred.

(2) As evidenced by its preamble, the Amendment was adopted "[w]ith obvious purpose to assure the continuation and render possible the effectiveness of [militia] forces.”

(3) The Amendment "must be interpreted and applied with that end in view."

(4) The right protected by the Second Amendment is not absolute, but instead is subject to government regulation.

My approach to this case, while involving the first three points, primarily concerns the fourth. ${ }^{192}$

It is not clear that Justice Breyer is even aware of the interpretationconstruction distinction. Suppose that that we amended his opinion by substituting the following for his point three:

(3) The Amendment must be construed with that end in view.

We might then read Justice Breyer as accepting Justice Scalia's interpretation of the Second Amendment's linguistic meaning, but arguing that the application of the amendment to particular cases should depend on constitutional construction. If this were correct, then Justice Breyer would believe that Justice Scalia accepts a role for construction because Justice Scaliawith all the Justices-accepts that the right is not absolute, "but instead is subject to government regulation.”

This reconstruction of Justice Breyer's dissent sheds light on the disagreement between himself and Justice Scalia on two issues: (1) the role of rational basis review, and (2) the role of balancing tests in the application of the Second Amendment. One of the most important passages in Justice

192 District of Columbia v. Heller, 128 S. Ct. 2783, 2848 (2008) (Breyer, J., dissenting) (citations omitted). 
Scalia's opinion occurs in footnote 27, where he responds to Justice Breyer's point that the District of Columbia ordinance would withstand rational basis scrutiny:

Justice BREYER correctly notes that this law, like almost all laws, would pass rational-basis scrutiny. But rational-basis scrutiny is a mode of analysis we have used when evaluating laws under constitutional commands that are themselves prohibitions on irrational laws. In those cases, "rational basis" is not just the standard of scrutiny, but the very substance of the constitutional guarantee. Obviously, the same test could not be used to evaluate the extent to which a legislature may regulate a specific, enumerated right, be it the freedom of speech, the guarantee against double jeopardy, the right to counsel, or the right to keep and bear arms. See United States v. Carolene Products Co., 304 U.S. 144, 152, n.4 (1938) ("There may be narrower scope for operation of the presumption of constitutionality [i.e., narrower than that provided by rationalbasis review] when legislation appears on its face to be within a specific prohibition of the Constitution, such as those of the first ten amendments. ..”). If all that was required to overcome the right to keep and bear arms was a rational basis, the Second Amendment would be redundant with the separate constitutional prohibitions on irrational laws, and would have no effect. ${ }^{193}$

Notice that Justice Scalia's analysis of rational basis scrutiny implicitly assumes the distinction between construction and interpretation. He argues that application of "rational basis scrutiny" would be inconsistent with the "substance"-semantic content or linguistic meaning-of the Second Amendment. In this vein, if rational basis scrutiny were applied, then the Second Amendment would have "no effect."

Tests like the rational basis test or balancing tests are not interpretations of the Constitution. Neither the Equal Protection Clause nor the Due Process Clause have "rational basis" or "balancing" as part of their linguistic meaning. Rather, such tests are subsidiary rules of constitutional construction. Justice Scalia's point is that the content of these subsidiary rules is constrained by the semantic content of the provision that is being construed. In other words, constitutional construction is constrained by constitutional interpretation.

Justice Scalia also responded to Justice Breyer's suggestion that a balancing test be used as the basis for construction of the Second Amendment:

Justice BREYER moves on to make a broad jurisprudential point: He criticizes us for declining to establish a level of scrutiny for evaluating Second Amendment restrictions. He proposes, explicitly at least, none of the traditionally expressed levels (strict scrutiny, intermediate scrutiny, rational basis), but rather a judge-empowering "interest balancing inquiry" that "asks whether the statute burdens a protected interest in a way or to an extent that is out of proportion to the statute's salutary effects upon other important governmental interests." After an exhaustive discussion of the arguments for and against gun

193 Id. at 2817 n.27 (majority opinion) (citations omitted). 
control, Justice BREYER arrives at his interest balanced answer: because handgun violence is a problem, because the law is limited to an urban area, and because there were somewhat similar restrictions in the founding period (a false proposition that we have already discussed), the interest-balancing inquiry results in the constitutionality of the handgun ban. QED.

We know of no other enumerated constitutional right whose core protection has been subjected to a freestanding "interest-balancing" approach. The very enumeration of the right takes out of the hands of government-even the Third Branch of Government - the power to decide on a case-by-case basis whether the right is really worth insisting upon. A constitutional guarantee subject to future judges' assessments of its usefulness is no constitutional guarantee at all. Constitutional rights are enshrined with the scope they were understood to have when the people adopted them, whether or not future legislatures or (yes) even future judges think that scope too broad. We would not apply an "interest-balancing" approach to the prohibition of a peaceful neo-Nazi march through Skokie. The First Amendment contains the freedom-of-speech guarantee that the people ratified, which included exceptions for obscenity, libel, and disclosure of state secrets, but not for the expression of extremely unpopular and wrong-headed views. The Second Amendment is no different. Like the First, it is the very product of an interest-balancing by the people-which Justice BREYER would now conduct for them anew. And whatever else it leaves to future evaluation, it surely elevates above all other interests the right of law-abiding, responsible citizens to use arms in defense of hearth and home. ${ }^{194}$

In this passage, Justice Scalia appears to endorse the core-andpenumbra approach to the Second Amendment. The second paragraph quoted above begins: "We know of no other enumerated constitutional right whose core protection has been subjected to a freestanding interestbalancing' approach.” Justice Scalia's view is that subsidiary rules of constitutional law-which provide constructions of vague constitutional content-must be consistent with the core linguistic meaning of the text.

\section{F. The Role of Constitutional Construction in the Future of the Second Amendment}

It is already clear that the there is much Second Amendment litigation to come, and it seems likely that "the right to keep and bear arms" will come before the Supreme Court on more than one occasion. A preliminary step will likely be the invalidation of municipal gun control ordinances that are similar to the District of Columbia's handgun ban. Those cases, however, will involve a question not addressed in Heller: whether the right to bear and keep arms applies to the states. Assuming that they do, the future of Second Amendment litigation seems likely to center on questions of constitutional construction. Once it is clear that bans on gun ownership are un-

194 Id. at 2821 (citations omitted) (emphasis added to “core”). 
constitutional, challenges are likely to focus on other regulations and restrictions - registration, licensing, qualifications for gun ownership, and requirements for the storage of guns. ${ }^{195}$

Justice Scalia's opinion for the Court clearly endorsed original public meaning originalism, but it did not endorse a particular method of constitutional construction. Of course, we can imagine that a future Supreme Court decision on the Second Amendment would involve a different configuration of Justices. Justice Kennedy might vote with the Heller dissenters to uphold a statute that Roberts, Scalia, Thomas, and Alito would strike down. If that happened, the originalist framework of Heller could be disturbed. But as things now stand, the crucial questions seem likely to focus on what constitutes an "infringement" and on what boundaries govern the right. Different methods of constitutional construction will yield different approaches to those questions, and potentially far different outcomes for particular challenges to particular restrictions on the possession and carrying of weapons.

\section{CONCLUSION: ORIGINALISM IN THEORY AND PRACTICE}

Heller is a case for the ages. It will be debated and discussed for years to come. For some, Heller will be significant as a landmark case on the meaning of the Second Amendment. For others, Heller will represent a barrier to effective gun control legislation or a vindication of the rights of gun owners. But it is at least possible that Heller's ultimate significance will lie in its long-term implications for the relationship between originalism as an academic theory of constitutional interpretation on the one hand, and as a component of constitutional practice on the other.

Heller is certainly the clearest and most prominent example of originalism in contemporary Supreme Court jurisprudence, but there is no guarantee that the majority opinion in Heller will have generative force. Heller was a 5-4 decision, and both the future composition of the Court and the votes of the current nine Justices are uncertain and unpredictable. One can imagine a future in which the Heller majority's originalist methodology becomes a matter of academic interest - an opinion that comes to be viewed as the short-lived zenith of originalism in constitutional practice. Nevertheless, it is at least possible to conceive of a world in which Heller represents a turning point in constitutional practice-the first step on a long journey from the instrumentalist constitutional jurisprudence that dominated the second half of the twentieth century towards a constitutional practice that emphasizes the importance of fidelity to the text and rigorous adherence to the rule of law.

If we are currently at a constitutional crossroads, the next step may be particularly momentous. When the Second Amendment returns to the Su-

\footnotetext{
195 See Gary E. Barnett, Note, The Reasonable Regulation of the Right to Keep and Bear Arms, 6 GEO. J.L. \& PUB. POL'Y 607 (2008).
} 
preme Court in a case challenging a state statute or local ordinance, the stakes will be high. The Court might retreat from Heller, perhaps as the result of a change in personnel or a change in heart. Alternatively, the Court might affirm Heller's endorsement of an individual right to possess and carry weapons but move away from its originalist reasoning. There is also at least one final possibility: the next step might be a decision that reverses the abandonment of original meaning in the Slaughter-House Cases. Such a decision would reverberate throughout constitutional jurisprudence. It would leave no doubt about the importance of originalist theory for constitutional practice. 
N ORTHW ESTER N UN IVER S T Y L A W R E VIE W 